\title{
A REVIEW OF THE CORROSION AND PYROPHORICITY BEHAVIOR OF URANIUM AND PLUTONIUM
}

by

Terry C. Totemeier

Argonne National Laboratory-West

Engineering Division

P.O. Box 2528

Idaho Falls, ID 83403

NON-APPLIED TECHNOLOGY

DISTRIBUTION OF THIS DOCUMENT IS UNLIMITED ${ }^{5}$ 
Argonne National Laboratory, with facilities in the states of Illinois and Idaho, is owned by the Linited States government, and operated by The University of Chicago under the provisions of a contract with the Department of Energy.

\section{DISCLAIMER}

This report was prepared as an account of work sponsored by an agency of the United States Government. Neither the United States Government nor any agency thereof, nor any of their employees, makes any warranty, express or implied, or assumes any legal liability or responsibility for the accuracy, completeness. or usefulness of any information, apparatus, product, or process disclosed, or represents that its use would not infringe privately owned rights. Reference herein to any specific commercial product, process, or service by trade name, trademark, manufacturer, or otherwise, does not necessarily constitute or imply its endorsement, recommendation, or favoring by the United States Government or any agency thereof. The views and opinions of authors expressed herein do not necessarily state or reflect those of the United States Government or any agency thereof.

Reproduced from the best available copy.

Available to DOE and DOE contractors from the

Office of Scientific and Technical Information

P.O. Box 62

Oak Ridge. TN 37831

Prices available from (615) 576-8401

Available to the public from the

National Technical Information Service

U.S. Department of Commerce

5285 Port Royal Road

Springfield, VA 22161 


\section{DISCLAIMER}

Portions of this document may be illegible in electronic image products. Images are produced from the best available original document. 
ABSTRACT $\ldots \ldots \ldots \ldots \ldots \ldots \ldots \ldots \ldots \ldots \ldots \ldots \ldots \ldots \ldots$ vii

INTRODUCTION $\ldots \ldots \ldots \ldots \ldots \ldots \ldots \ldots \ldots \ldots \ldots \ldots \ldots \ldots \ldots \ldots \ldots$

PART I. URANIUM $\ldots \ldots \ldots \ldots \ldots \ldots \ldots \ldots \ldots \ldots \ldots \ldots \ldots \ldots \ldots$

1. Oxidation and Corrosion $\ldots \ldots \ldots \ldots \ldots \ldots \ldots \ldots \ldots \ldots \ldots \ldots \ldots \ldots \ldots$

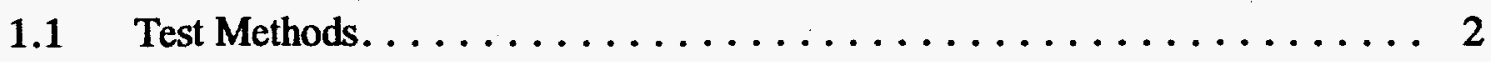

1.2 Gaseous Oxidation .................... 3

1.2.1 Oxygen and Dry Air $\ldots \ldots \ldots \ldots \ldots \ldots \ldots \ldots \ldots \ldots$

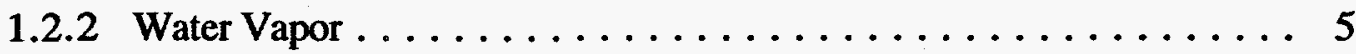

1.2.3 Water Vapor-Oxygen $\ldots \ldots \ldots \ldots \ldots \ldots \ldots \ldots \ldots$

1.2.4 Effect of Prior Irradiation $\ldots \ldots \ldots \ldots \ldots \ldots \ldots \ldots \ldots \ldots$

1.2.5 Oxidation of Uranium-Zirconium Alloys $\ldots \ldots \ldots \ldots \ldots \ldots 11$

1.2.6 Oxidation of Uranium-Plutonium Alloys $\ldots \ldots \ldots \ldots \ldots \ldots 12$

$1.3 \quad$ Aqueous Corrosion $\ldots \ldots \ldots \ldots \ldots \ldots \ldots \ldots \ldots \ldots \ldots$

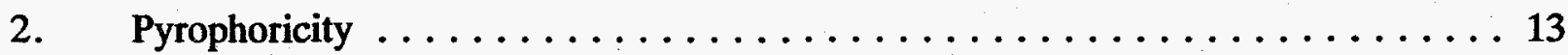

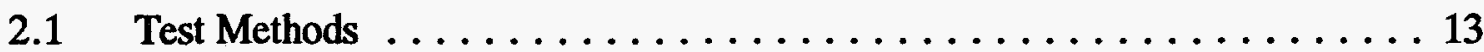

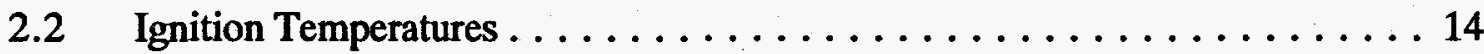

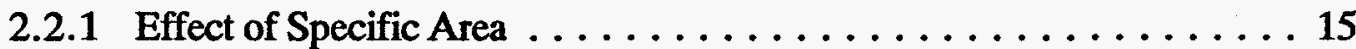

2.2.2 Effect of Gas Composition ................. 15

2.2.3 Ignition of Uranium-ZirconiumAlloys $\ldots \ldots \ldots \ldots \ldots \ldots \ldots 16$

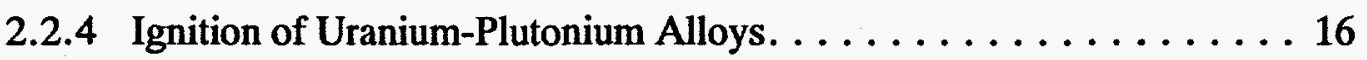

$2.3 \quad$ Ignition Models $\ldots \ldots \ldots \ldots \ldots \ldots \ldots \ldots \ldots \ldots \ldots \ldots \ldots \ldots \ldots \ldots$

3. Implications for Storage Issues $\ldots \ldots \ldots \ldots \ldots \ldots \ldots \ldots \ldots \ldots \ldots \ldots$

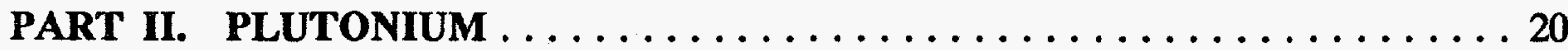

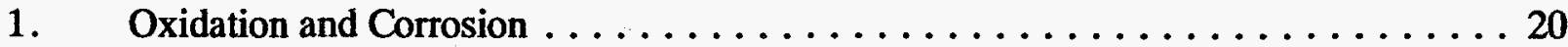


TABLE OF CONTENTS (Contd.)

Page

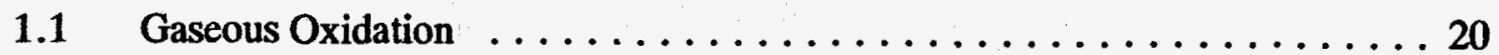

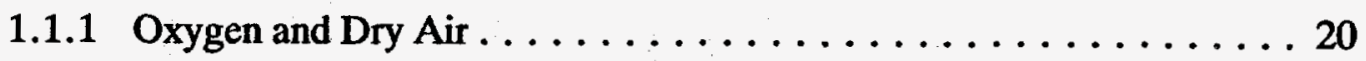

1.1.2 Water Vapor-Oxygen ................... 22

1.1.3 Oxidation of Plutonium Alloys $\ldots \ldots \ldots \ldots \ldots \ldots \ldots \ldots 24$

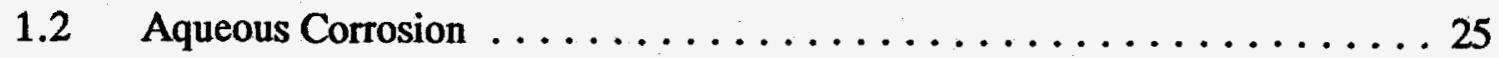

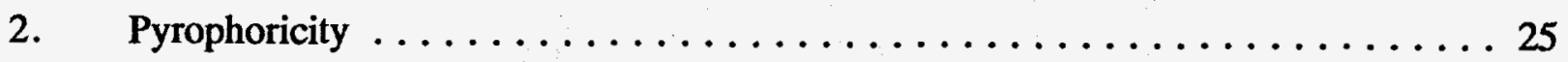

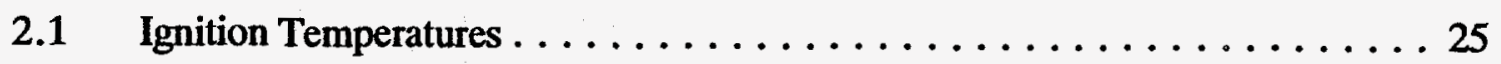

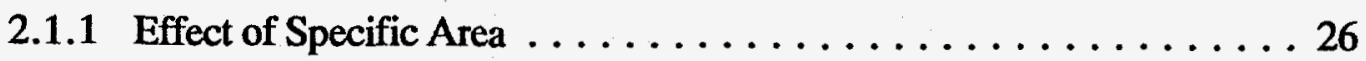

2.1.2 Effect of Gas Composition $\ldots \ldots \ldots \ldots \ldots \ldots \ldots \ldots$

2.1.3 Effect of Prior Storage $\ldots \ldots \ldots \ldots \ldots \ldots \ldots \ldots \ldots \ldots \ldots \ldots \ldots$

2.1.4 Ignition of Plutonium Alloys $\ldots \ldots \ldots \ldots \ldots \ldots \ldots \ldots \ldots 27$

2.2 Ignition Models $\ldots \ldots \ldots \ldots \ldots \ldots \ldots \ldots \ldots \ldots \ldots \ldots \ldots$

3. Implications for Storage Issues $\ldots \ldots \ldots \ldots \ldots \ldots \ldots \ldots \ldots \ldots \ldots \ldots \ldots \ldots$

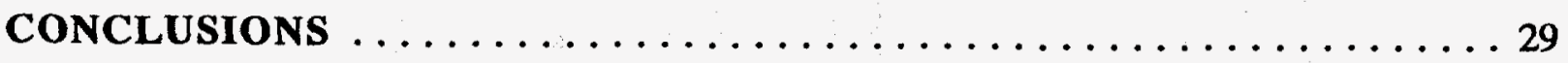

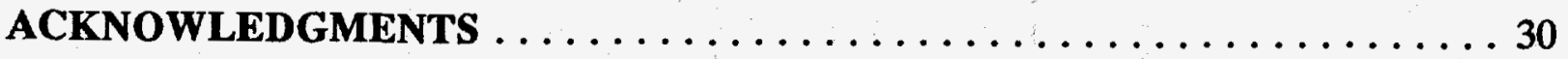

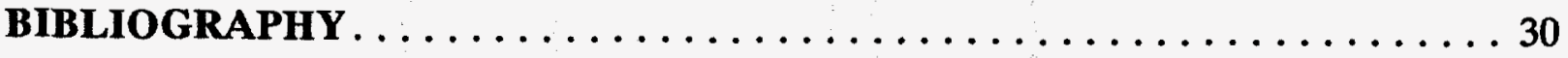




\section{LIST OF TABLES}

Page

I. Summary Table for Uranium Reaction with Dry Air $\mathrm{O}_{2} \ldots \ldots \ldots \ldots \ldots$

II. Summary Table for Uranium Reaction with Water Vapor . . . . . . . . . . . 39

III. General Factors Influencing the Rates of Generation and Loss of Heat in Ignition . . 43

IV. Summary Table for Plutonium Reaction with Dry Air $/ \mathrm{O}_{2} \ldots \ldots \ldots \ldots \ldots$

V. Summary Table for Plutonium Reaction with Water Vapor $\ldots \ldots \ldots \ldots \ldots$ 


\section{LIST OF FIGURES}

1. Variations of hydrogen, oxygen, and water vapor gas concentrations with time during the reaction of uranium with a water vapor - oxygen mixture.

2. Oxidation rates of uranium and a U-6w/oZr alloy (quenched from $850^{\circ} \mathrm{C}$ ) at $75^{\circ} \mathrm{C}$ in air containing $50 \%$ relative humidity.

3. Variation of paralinear reaction rate constants for uranium and a $\mathrm{U}-20 \mathrm{w} / \mathrm{OZr}$ alloy in gaseous oxygen.

4. Uranium ignition temperatures for solid specimens as a function of specific area. . . 48

5. Ignition temperatures of uranium powders in oxygen as a function of specific area. . . 49

6. The effect of oxygen concentration on uranium ignition and burning temperatures of $8.5 \mathrm{~mm}$ uranium cubes.

7. Oxidation rates observed for plutonium in oxygen and dry air as a function of temperature.

8. Variation in plutonium oxidation rates with humidity.

9. The effect of several alloying additions on the oxidation rate of plutonium at $35^{\circ} \mathrm{C}$ in

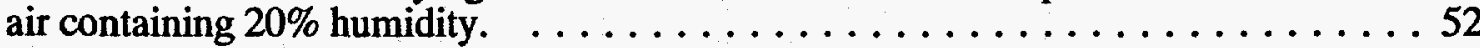

10. The effect of $\mathrm{Ga}$ alloying additions on the oxidation rate of plutonium at $75^{\circ} \mathrm{C}$ in dry

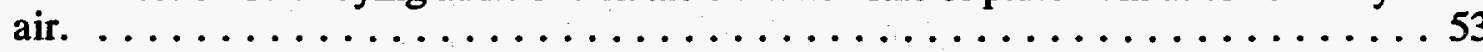

11. The variation in plutonium corrosion rates in aqueous solutions at room temperature with anion concentraton. . . . . . . . . . . . . . . . . . 54

12. Compliation of plutonium ignition temperatures in air and oxygen as a function of specific area.

13. Variation of plutonium ignition and burning temperatures with oxygen concentration in $\mathrm{N}_{2}-\mathrm{O}_{2}$ mixtures. 55

14. Variation of ignition temperatures in air with specific area for $\mathrm{Pu}-2 \mathrm{a} / \mathrm{oX}$ alloy foils. . . 55 


\title{
A REVIEW OF THE CORROSION AND PYROPHORICITY BEHAVIOR OF URANIUM AND PLUTONIUM
}

by

\author{
Terry C. Totemeier
}

\begin{abstract}
This report presents a review of the corrosion and pyrophoricity behavior of uranium and plutonium. For each element, the reactions with oxygen, water vapor, and aqueous solutions are described in terms of reaction rates, products, and mechanisms. Their pyrophoric tendencies in terms of measured ignition temperatures are discussed, and the effects of the important variables specific area, gas composition, and prior storage are stated. The implications of the observed behavior for current storage issues are considered.

The oxidation behaviors of uranium and plutonium are very similar. Both react readily with oxygen at room temperature, forming a product which is composed principally of metal dioxide. Addition of water vapor to the oxidizing gas increases reaction rates for both elements; however reaction rates are highest in water vapor - inert gas atmospheres, as the presence of oxygen retards the metal - water vapor reaction. The oxidation process for both metals occurs under anodic control with mass transport accomplished by oxygen or hydroxide ion diffusion through the as-forming oxide. Hydrogen-containing products such as hydrides, hydroxides, and hydrated oxides are formed along with oxide in the reaction with water in both the vapor and liquid forms. Alloying with zirconium improves the oxidation resistance of both metals.

Uranium and plutonium also show similar ignition behavior and are strongly pyrophoric in certain forms. Specific area (area per unit mass) exerts the strongest influence on measured ignition temperatures. Both metals show a sharp transtion from high, relatively constant ignition temperatures for massive samples (low specific areas) to low ignition temperatures for foils, powders, and fines (high specific areas).

The principal implication of the observed behavior for storage issues is that a compromise must be found between storage environments which minimize attack due to gaseous oxidation and environments which minimize risk of spontaneous ignition and explosions of finely divided metal pieces. Oxidation is minimized for both metals by storage in flowing dry air (oxygen-containing) environments, while the pyrophoricity risk is minimized by removal of oxygen.
\end{abstract}




\section{INTRODUCTION}

The recent emphasis by the Department of Energy (DOE) on determining effective disposal options and procedures for nuclear waste, spent nuclear fuel (SNF), and weapons grade plutonium has led to a re-emergence of interest in the oxidation, corrosion, and pyrophoricity behavior of the primary fuel elements uranium and plutonium. These two metals are of particular concern due to the quantities in which they are present within the DOE complex and their radioactive and pyrophoric nature.

The continuing need for understanding of the behavior of uranium and plutonium has been underscored by several incidents involving these two materials in the DOE complex and at Argonne National Laboratory - West (ANL-W). Two recent incidents experienced at ANL-W are the excessive corrosion and bulging of Zero Power Physics Reactor (ZPPR) uranium fuel plates (Solbrig et al., 1994; Longua, 1991), and sparking from a U-10Zr casting heel following one year of storage in a sealed canister (Villarreal and Krsul, 1990). In addition, several sealed canisters containing plutonium have increased in weight during extended storage at ANL-W (Crawford, 1994). There also have been other reported incidents relating to the storage behavior of uranium and plutonium within the DOE complex (Sliva, 1992; Wood et al., 1994).

Most of the initial studies of the oxidation and ignition behavior of uranium and plutonium were performed in the 1950 's and 60 's to insure safety during processing procedures. Information was also needed concerning expected corrosion rates in reactor environments. Several reviews of the literature concerning the oxidation of uranium and plutonium summarizing the results of these studies have been performed (Wilkinson, 1962; Waber, 1967; Stakebake, 1971; Orman, 1974; Cathcart, 1974; Colmenares, 1975, 1984; Ritchie, 1981; Stakebake, 1992b). The usefulness of these reviews in consideration of storage issues is in fact somewhat limited due to their scope, as each review generally only concerns itself with a specific topic (e.g. uranium oxidation). In addition, there have been several additional studies performed since the last review which clarify the mechanisms of degradation and are especially relevant to current storage problems.

This report is a summary and review of the information available concerning the oxidation, corrosion, and pyrophoricity behavior of uranium and plutonium relevant to the current problems of waste management and storage. For both metals the oxidation behavior in both dry and humid air for temperatures up to $-300^{\circ} \mathrm{C}$ is discussed, with detailed descriptions of the reaction rates, products, and mechanisms, as well as the effects of humidity level, prior irradiation, and alloying additions. The aqueous corrosion of both metals is also described. The pyrophoric tendencies of 
uranium, plutonium, and their alloys are described in terms of measured ignition temperatures; models developed to predict ignition temperatures on the basis of thermodynamic and kinetic information for each metal are presented. For each metal, the implications of the observed behavior for the current problems of waste storage and handling are also discussed.

\section{PART I. URANIUM}

\section{OXIDATION AND CORROSION}

\subsection{TEST METHODS}

The kinetics of oxidation and corrosion of uranium and plutonium are usually characterized in terms of a reaction rate constant $k$. This constant is related to either the weight gain of the specimen per unit area or the amount of metal reacted per unit area by an equation with the general form:

$$
\frac{\Delta W}{A}=k t^{n}
$$

where $\Delta W$ is the weight gain of the specimen (due to incorporation of oxygen in the reaction product) or the mass of metal reacted, $A$ is the reacting surface area of the specimen, $t$ is time, and $n$ is an exponential factor which is determined empirically. The exponential term $n$ will be $1 / 2$ for parabolic oxide growth and unity for linear oxide growth. Parabolic growth kinetics are characteristic of diffusion-controlled growth of a coherent oxide film, while linear kinetics can be characteristic of reaction rate controlled growth, diffusion-controlled growth through a coherent oxide film of constant thickness, or transformation of one reaction product to another. The reaction rate is itself dependent on a number of factors, including temperature, pressure, gas composition, and metal composition. The reaction rate is typically thermally activated; i.e.

$$
k=C \exp \left[\frac{-E}{R T}\right]
$$

where $C$ is a pre-exponential term, $E$ is the activation energy for the reaction, $R$ is the universal gas constant, and $T$ is the absolute temperature. $C$ and $E$ are determined from a plot of $\log k$ versus $1 / T$. 
Two methods are principally used to measure the kinetics of the oxidation and corrosion of uranium and plutonium. The most common method is a continuous measurement of the specimen mass while the specimen is exposed to the oxidizing environment via a gravimetric mass balance. The environment is controlled for gaseous oxidation by a gas/vacuum manifold, or through the composition of a reacting water solution for aqueous corrosion. Some researchers have measured mass changes by periodic specimen weighing, either as-reacted or after oxide removal in an acid bath. Alternatively, the amount of gas reacted can be measured for closed systems using a manometer or other pressure-sensing device.

Post-test analysis to determine the composition of the reaction products is commonly carried out using metallography, $X$-ray diffraction (XRD), gas chromatography, and more recently using advanced surface techniques such as auger electron spectroscopy (AES) and $\mathrm{X}$-ray photoelectron spectroscopy (XPS). Isotopic studies using $18 \mathrm{O}$ have also been performed (Baker et al., 1966; McGillivray et al., 1994) to determine the source of reacting oxygen in metaloxygen-water reactions.

\subsection{GASEOUS OXIDATION}

\subsubsection{Oxygen and Dry Air}

Uranium reacts readily with pure oxygen or dry air to form slightly superstoichiometric $\mathrm{UO}_{2}$ via the reaction (Colmenares, 1975)

$$
\mathrm{U}+\frac{2+x}{2} \mathrm{O}_{2} \rightarrow \mathrm{UO}_{2+x} .
$$

Uranium has a much greater affinity for oxygen than for nitrogen or carbon dioxide. The initial oxide color is yellow, but changes to brown-black as oxidation proceeds and the oxide becomes non-protective. At temperatures above $\sim 300^{\circ} \mathrm{C} \mathrm{U}_{3} \mathrm{O}_{8}$ is formed (Wilkinson, 1962).

The gaseous oxidation of uranium at temperatures below $400^{\circ} \mathrm{C}$ has been investigated by several researchers (Waber, 1958; Liebowitz et al., 1961; Bennett et al., 1974,1975; Bennett and Price, 1981; Ritchie, 1984b; McGillivray, 1994), and has been reviewed by Wilkinson (1962), Orman (1976), Ritchie (1981), and Colmenares $(1974,1984)$. Table I shows a summary of studies of the reaction of uranium with dry air or oxygen. The initial kinetics of the reaction have been reported to be linear, parabolic, or "paralinear", although more recent studies support parabolic or paralinear kinetics rather than linear kinetics. A subsequent transition 
from the initial kinetic behavior to a higher linear rate is commonly observed. The final linear rate of oxidation is of greatest interest for longer-term storage problems. The variation in linear reaction rate constants for oxidation of uranium in dry air with temperature as measured in several studies was determined by Ritchie (1981) to be:

$$
k=6.9 \times 10^{8} \exp \left[\frac{-18,300}{R(\mathrm{cal} / \mathrm{mol} \cdot \mathrm{K}) T(\mathrm{~K})}\right] \frac{\mathrm{mg} \mathrm{U}}{\mathrm{cm}^{2} \cdot \mathrm{hr}}
$$

This relation is valid in the temperature range $40 \leq T\left(^{\circ} \mathrm{C}\right) \leq 300$.

In his review, Colmenares (1984) stated that the kinetics of uranium oxidation in dry air are in fact "paralinear" rather than linear, with the total rate being a combination of linear and parabolic components:

$$
\frac{\Delta W}{A}=C+k_{p} t^{1 / 2}+k_{l} t
$$

where $C$ is a constant, $k_{p}$ is the parabolic rate constant, and $k_{l}$ is the linear rate constant. While this form of the kinetic rate law is theoretically more correct and has greater significance in terms of reaction mechanisms, at longer times the linear approximation used by Ritchie (1981) is empirically valid and also simple to use.

As mentioned above, the product of the uranium and oxygen reaction at temperatures below $-300^{\circ} \mathrm{C}$ is superstoichiometric uranium dioxide, $\mathrm{UO}_{2+x}$. The value of $x$ has been observed to vary from 0.2 to 0.4 (Orman, 1976). Colmenares $(1975,1984$ ) has described the structure and properties of uranium oxides in great detail in two review papers, as the structure of defects and means of electric conduction within the oxide will determine the influences of important variables on the oxidation process. The point most relevant to the current discussion is that lattice defects in the oxide occur in charged complexes of lattice vacancies and interstitial oxygen atoms. These defect complexes, and the accompanying electron holes necessary for conservation of charge, conduct electric charge in the oxide.

The mechanism of the uranium-oxygen reaction, or any gaseous oxidation process, can be separated into six steps (Wilkinson, 1962):

1. Transport of oxygen gas molecules through the gas to the oxide.

2. Adsorption of oxygen molecules onto the oxide surface.

3. Dissociation of oxygen molecules into oxygen atoms. 
4. Ionization of oxygen atoms at the oxide surface and uranium atoms at the oxide-metal interface (controlled by conduction of charge through the oxide).

5. Diffusion of oxygen ions through the oxide driven by an ion concentration gradient in the oxide.

6. Reaction of oxygen ions with uranium ions at the oxide-metal interface.

The initial parabolic rate law commonly observed for uranium oxidation in air suggests that the rate-limiting step of the initial uranium oxidation process is the diffusion of oxygen ions through a growing coherent oxide lattice. Ritchie (1984b) suggested that this diffusion process is controlled by the electric field of the oxide at temperatures below $100^{\circ} \mathrm{C}$, which leads to a inverse logarithmic form of the rate equation, a form which is slightly different than the parabolic form. Above $100^{\circ} \mathrm{C}$ the kinetics are controlled by thermal diffusion and the resulting rates are parabolic. That oxygen is the diffusing species in $\mathrm{UO}_{2+x}$ was verified by Schnizlein et al. (1959) using platinum markers; oxygen ions diffuse through the oxide in interstitial positions.

As the coherent oxide grows, large compressive stresses are generated in the oxide due to the large lattice parameter and density mismatch between the oxide and the uranium substrate. These stresses are relieved by cracking and spallation in the outer layers of the oxide. The transition to linear kinetics has been related to the onset of oxide cracking, with the linear rate controlled by diffusion of oxygen ions through a coherent layer of oxide whose thickness remains roughly constant as oxidation proceeds. The activation energies observed (average of $18 \mathrm{kcal} / \mathrm{mol}$ by Ritchie (1981)) for both the initial and final rates are similar to that observed for diffusion of oxygen in $\mathrm{UO}_{2+x}$. In the paralinear scheme proposed by Colmenares (1984) the linear component was representative of the rate of uranium-oxygen reaction at the metaloxide interface, with the parabolic component representative of diffusion through the oxide film.

\subsubsection{Water Vapor}

Since the free energy of formation of $\mathrm{UO}_{2}$ is lower than that of $\mathrm{H}_{2} \mathrm{O}(122$ $\mathrm{kcal} / \mathrm{mol}$ of $\mathrm{O}$ compared to $57 \mathrm{kcal} / \mathrm{mol}$ of $\mathrm{O}$ ), water will oxidize uranium to $\mathrm{UO}_{2}$. The rates of reaction of uranium with water vapor are significantly higher than those for pure oxygen (Orman, 1963; Baker et al., 1966a and b; Bennett et al., 1975; Ritchie et al., 1986; Weirick, 1984; McGillivray et al., 1994). Table II summarizes the results of studies of the reaction of uranium with water vapor. The net reaction can be represented by: 


$$
\mathrm{U}+(2+x) \mathrm{H}_{2} \mathrm{O} \rightarrow \mathrm{UO}_{2+x}+(2+x) \mathrm{H}_{2}
$$

As with the reaction with oxygen, Baker et al. (1966a) found the oxide formed by the reaction of uranium with water to be slightly superstoichiometric, with $x$ approximately 0.06 to 0.11 . In more recent studies, Ritchie (1981, 1984), Colmenares et al. (1981), and Weirick (1984) have reported the formation of stoichiometric $\mathrm{UO}_{2}(x=0)$.

The rates of reaction of saturated water vapor ( $100 \%$ relative humidity) with uranium have been reviewed by Ritchie (1981). Similar to the dry air oxidation data, the kinetics of the reactions were initially linear or parabolic with linear final oxidation rates. Ritchie fitted the available data to a linear rate equation, with $k$ given by:

$$
k=3.2 \times 10^{8} \exp \left[\frac{-13,800}{R(\mathrm{cal} / \mathrm{mol} \cdot \mathrm{K}) T(\mathrm{~K})}\right] \frac{\mathrm{mg} \mathrm{U}}{\mathrm{cm}^{2} \cdot \mathrm{hr}}
$$

This relation is applicable in the temperature range $20 \leq T\left({ }^{\circ} \mathrm{C}\right) \leq 100$. The activation energies for oxidation by oxygen and water are similar, suggesting a similar rate-determining mechanism.

In later work, Ritchie (1984a) reviewed the dependence of reaction rates on water vapor pressure as measured by several researchers. Linear reaction rates were dependent on the square root of the water vapor pressure in torr according to the relation:

$$
k=1.3 \times 10^{4} P_{\mathrm{H}_{2} \mathrm{O}^{1 / 2}} \exp \left[\frac{-9,000}{R(\mathrm{cal} / \mathrm{mol} \cdot \mathrm{K}) T(\mathrm{~K})}\right] \frac{\mathrm{mg} \mathrm{U}}{\mathrm{cm}^{2} \cdot \mathrm{hr}}
$$

or in terms of relative humidity:

$$
k=3.5 \times 10^{8} r^{1 / 2} \exp \left[\frac{-14,100}{R(\mathrm{cal} / \mathrm{mol} \cdot \mathrm{K}) T(\mathrm{~K})}\right] \frac{\mathrm{mg} \mathrm{U}}{\mathrm{cm}^{2} \cdot \mathrm{hr}}
$$

where $r$ is the fractional relative humidity (i.e. for $70 \%$ relative humidity $r=0.70$ ). There is good agreement with the rate given by equation 9 for $100 \%$ relative humidity and equation 7 , which was derived using separate data.

With the exception of Baker et al. (1966a), the primary reaction product of the $\mathrm{U}-\mathrm{H}_{2} \mathrm{O}$ (vap) reaction is universally reported to be $\mathrm{UO}_{2}$, as mentioned above. However, less than the stoichiometric amount of hydrogen expected to be generated according to equation (6) has been observed, and several authors report the presence, detected by various means, of small 
amounts of uranium hydride $\mathrm{UH}_{3}$ (Kondo et al., 1964, 1974; Baker et al., 1966a; Winer et al., 1987), uranium hydroxide $\mathrm{U}(\mathrm{OH})_{3}$ (Waber, 1958), or a hydrated uranium oxide $\mathrm{UO}_{2+x} \cdot y \mathrm{H}_{2} \mathrm{O}$ (Waber, 1958; Wilkinson, 1962) to account for the deficient hydrogen. Of these compounds, uranium hydride is the most consistently and conclusively observed. Data proving the existence of the latter two compounds is lacking.

The mechanism of uranium oxidation by water vapor is similar to the dry air oxidation mechanism. The first step is the adsorption of a water molecule onto the oxide surface. Winer et al. (1987) postulate that the dissociation of the water molecule occurs on the surface via a hydrolysis reaction:

$$
\mathrm{H}_{2} \mathrm{O}(s)+\mathrm{O}^{2-}(l \text { or } i) \rightarrow \mathrm{OH}^{-}(l \text { or } i)+\mathrm{OH}^{-}(s)
$$

where $(s)$ denotes a surface site, $(l)$ an oxide lattice site, and $(i)$ an oxide interstitial site. This mechanism is consistent with the dependence of reaction rates on water vapor pressure determined by Ritchie (1984a). Another suggested scheme is a simple dissociation of the water molecule to form $\mathrm{H}^{+}$and $\mathrm{OH}^{-}$ions, with the subsequent evolution of molecular hydrogen at the oxide surface (Baker et al., 1966a). In either case $\mathrm{OH}^{-}$ions diffuse through the oxide lattice in the same way that $\mathrm{O}^{2-}$ ions diffuse in the case of dry air oxidation. The diffusion of $\mathrm{OH}^{-}$-ions through the oxide lattice requires less energy than diffusion of $\mathrm{O}^{2-}$ ions due to a lower Coulomb force opposing their movement (Colmenares, 1984). This is one possible explanation for the increased oxidation rates observed for water vapor compared to dry air oxidation. Another possibility is the loss of coherence (perhaps due to the incorporation of hydrogen containing compounds), and hence protective nature, for oxides formed by reaction with water (Kondo et al., 1964, 1974).

At the oxide-metal interface $\mathrm{OH}^{-}$ions react with uranium atoms to form $\mathrm{UO}_{2}$ or $\mathrm{UO}_{2+x}$. Ritchie (1984a) proposed that water reacts with excess oxygen in the oxide lattice $\left(\mathrm{O}^{2-}(i)\right)$ during the dissociation step (equation 10) to reduce $\mathrm{UO}_{2+x}$ to $\mathrm{UO}_{2}$. Several different possibilities have been suggested as to the fate of the hydrogen. Baker et al. (1966a) suggest that $\mathrm{UH}_{3}$ is formed as an intermediate product in the reaction between hydroxide ions and uranium atoms. They propose that $\mathrm{UH}_{3}$ then further reacts with water to form uranium oxide and hydrogen gas, with a small amount of the hydride still present in the reaction product. Winer et al. (1987) proposed that the reaction of hydroxide ions and uranium atoms produces uranium oxide and protons. The protons combine to form $\mathrm{H}_{2}$ which either diffuses to the oxide surface or reacts with uranium to form $\mathrm{UH}_{3}$. Waber (1958) suggests that the hydroxide ions react directly with uranium to form a hydroxide, while both Waber and Wilkinson (1962) state that water molecules can be 
adsorbed on the oxide surface as a hydrated uranium oxide. Most experimental evidence supports the formation of uranium hydride.

\subsubsection{Water Vapor-Oxygen}

Oxygen has a strong inhibiting effect on the oxidation of uranium by water vapor. The addition of oxygen to the uranium-water vapor system considerably slows the rate of reaction (Kondo et al., 1964; Ritchie, 1981; Baker et al., 1966b; Colmenares et al., 1981; Colmenares, 1984), although these rates are still greater than those observed for the reaction with dry air. The effect of water vapor pressure (relative humidity) in the uranium-oxygen-water vapor system has been investigated by a number of researchers (Bennett et al., 1975; Ritchie et al., 1986; McGillivray et al., 1994). The reaction rate increases as water vapor is added to the uraniumoxygen system, up to a relative humidity $(\mathrm{RH})$ of $1-2 \%$. In the humidity range from $1-2 \%$ to about $90 \%$ the reaction rate is constant with respect to humidity (Ritchie et al., 1986); above 90\% the rate increases again. The rates observed in the different humidity ranges have been compiled by Ritchie (1981). In the constant rate range of $2 \% \mathrm{RH}$ to $90 \% \mathrm{RH}$ the variation of rate with temperature is given by the relation:

$$
k=4.8 \times 10^{13} \exp \left[\frac{-25,000}{R(\mathrm{cal} / \mathrm{mol} \cdot \mathrm{K}) T(\mathrm{~K})}\right] \frac{\mathrm{mg} \mathrm{U}}{\mathrm{cm}^{2} \cdot \mathrm{hr}}
$$

The relation is valid in the temperature range $40 \leq T\left({ }^{\circ} \mathrm{C}\right) \leq 130$. At $100 \% \mathrm{RH}$ the temperature dependence of $k$ is given by:

$$
k=4.6 \times 10^{9} \exp \left[\frac{-17,800}{R(\mathrm{cal} / \mathrm{mol} \cdot \mathrm{K}) T(\mathrm{~K})}\right] \frac{\mathrm{mg} \mathrm{U}}{\mathrm{cm}^{2} \cdot \mathrm{hr}}
$$

This relation is valid in the temperature range $25 \leq T\left({ }^{\circ} \mathrm{C}\right) \leq 100$.

McGillivray et al. (1994) performed a detailed investigation of the uraniumoxygen-water vapor reaction at higher temperatures $\left(115^{\circ} \mathrm{C}\right.$ to $\left.350^{\circ} \mathrm{C}\right)$. At these temperatures the "plateau" of reaction rates from $2 \%$ to $90 \%$. $\mathrm{RH}$ was not observed. A model was developed based on a Langmuir-type monolayer adsorption isotherm which predicted rates as a function of temperature and water vapor pressures: 


$$
k_{\text {net }}=\frac{k_{1} P}{1+k_{2} P}+D
$$

with

$$
\begin{aligned}
& D=3.94 \times 10^{6} \exp (-8,077 / T(\mathrm{~K})) \\
& k_{1}=1.51 \times 10^{5} \exp (-6,432 / T(\mathrm{~K})) \\
& k_{2}=2.02 \times 10^{8} \exp (-5,327 / T(\mathrm{~K}))
\end{aligned}
$$

where $P$ is water vapor pressure in $\mathrm{kPa}$, and $D, k_{\text {net }}, k_{1}$, and $k_{2}$ are in $\mathrm{mg} / \mathrm{cm}^{2} \cdot \mathrm{hr}$. The relation is valid in the temperature range of $115 \leq T\left({ }^{\circ} \mathrm{C}\right) \leq 350$ and the water vapor pressure range $0-47 \mathrm{kPa}$.

The products of the uranium-oxygen-water vapor reaction are nominally identical to the products of the uranium-water vapor reaction, i.e. mostly $\mathrm{UO}_{2}$ or $\mathrm{UO}_{2+x}$ with some uranium hydride, hydroxide, or hydrated oxide. Both Colmenares et al. (1981) and Weirick (1984) report the formation of a super-stoichiometric oxide more similar to the product of the uranium-oxygen reaction, compared to stoichiometric $\mathrm{UO}_{2}$ formed in the uranium-water vapor reaction. The source of the oxygen (from either the water vapor or gaseous oxygen) that reacts to form $\mathrm{UO}_{2+x}$ has been investigated using ${ }^{18} \mathrm{O}$ isotopic tracer studies. The reported results differ. Baker et al. (1966b) reported that at $25-100^{\circ} \mathrm{C}$ all of the oxygen in the oxide was derived from water molecules via hydrolysis, but also that all of the hydrogen generated in the hydrolysis reaction subsequently re-formed water molecules with oxygen from in the gas phase, according to the reaction sequence below, where $\mathrm{G} O$ signifies oxygen derived from oxygen gas and $(s)$ denotes a surface-adsorbed species:

$$
\begin{aligned}
& \mathrm{O}_{2}(g)+2 e^{-} \rightarrow 2^{\mathrm{G}} \mathrm{O}^{-}(s) \\
& \mathrm{H}_{2} \mathrm{O}(g) \rightarrow \mathrm{H}^{+}(s)+\mathrm{OH}^{-}(s) \\
& \mathrm{GO}^{-}(s)+\mathrm{H}^{+}(s) \rightarrow \mathrm{GOH}^{-}(s)
\end{aligned}
$$

$\mathrm{OH}^{-}(s)$ diffuses to the metal-oxide interface and reacts liberating $\mathrm{H}^{\bullet}$ which diffuses to the oxidegas interface and reacts to reform water:

$$
\mathrm{H} \cdot+\mathrm{GOH} \cdot(s) \rightarrow \mathrm{H}_{2} \mathrm{GO}(g)
$$

Hence there was no hydrogen generation or consumption of water in the net reaction while gaseous oxygen was present in the system. When all of the gaseous oxygen was consumed (converted into water), the reaction proceeded as a uranium-water vapor reaction with hydrogen gas generation. The behavior is shown clearly in Fig. 1, which shows the concentrations of the various species as a function of time. There is no hydrogen generation or water consumption until all oxygen is consumed. 
Weirick (1984) later performed a similar isotopic study at $100^{\circ} \mathrm{C}$, and postulated that oxygen reacting to form $\mathrm{UO}_{2}$ was derived from the gas phase, contrary to the findings of Baker et al. described above. Supporting evidence for this hypothesis was provided by the isotopic compositions of reaction products, the stoichiometry of the reaction product, and the reaction rates observed. Weirick postulated that the results reported by Baker et al. were affected by spurious production of $\mathrm{H}_{2}{ }^{18} \mathrm{O}$. A third study was performed by McGillivray et al. (1994), but at higher temperatures $\left(115-300^{\circ} \mathrm{C}\right.$ compared to $25-100^{\circ} \mathrm{C}$ and $100^{\circ} \mathrm{C}$ ), who found that both water and gaseous oxygen contribute oxygen to the oxide, in ratios which depend on the respective contributions of water and oxygen to the overall reaction rate. The reason for the inconsistency of this result with the previous studies was not identified, however the difference in temperatures considered could have led to the observed difference in mechanism.

It is generally believed that the mechanism by which gaseous oxygen retards the uranium-water vapor reaction is the formation of a monolayer of adsorbed or chemisorbed oxygen atoms on the oxide surface, which serves to block the adsorption of water molecules. Only a very small concentration of oxygen is needed to fully retard the reaction rate, $0.1 \%$ by volume of oxygen (Colmenares, 1984). Hence when oxygen is present, transport of oxygen through the oxide would take place via the diffusion of $\mathrm{O}^{2-}$ ions rather than $\mathrm{OH}^{-}$ions. In the mechanism proposed by Baker et al. (1966b) and described above, the $\mathrm{O}^{2-}$ ions are actually derived from the water molecules but equal amounts of oxygen from the gas is converted into water to compensate. Later work by Weirick (1984) presented evidence suggesting that oxygen is derived directly from oxygen gas, a statement which was backed by Colmenares (1984).

The findings of the study by McGillivray et al. mentioned above strongly suggested that in fact both $\mathrm{O}^{2-}$ and $\mathrm{OH}^{-}$ions are transported through the oxide during the reaction of uranium with oxygen and water vapor, i.e. both gaseous oxygen and water vapor react simultaneously. According to their proposed mechanism, the reduction of reaction rate with respect to the pure water vapor reaction is still due to the formation of a monolayer of oxygen atoms on the oxide surface. Water molecules can reach the oxide to react, but at a rate slower than in the pure water reaction. Evidence for this mechanism was provided by the isotopic composition of the oxide as reported above, and by the successful fit of experimental data to the theoretical model created assuming this mechanism was operative. 


\subsubsection{Effects of Prior Irradiation}

The effects of prior irradiation on the oxidation behavior of uranium in dry and moist air was thoroughly investigated in a series of papers by Pearce, Bennett, and Price (Bennett et al., 1975; Bennett and Price; 1981; Bennett et al., 1985; Pearce et al., 1988). Irradiation was found to increase oxidation by a factor of two at minimum, and was strictly dependent on the degree of irradiation-induced swelling. Oxidation rates were enhanced by a factor $F$ which was defined as:

$$
k=k_{0} F
$$

with

$$
F=\exp \left[\frac{8.43 \times 10^{-3}}{T^{2}} S\right]
$$

where $k_{0}$ is the unirradiated rate, $S$ is the percentage of irradiation-induced swelling, and $T$ is the absolute temperature. This factor was used with the proviso that $F$ has a minimum value of two regardless of the values of $S$ and $T$, as an intrinsic enhancement factor of two due to irradiation was observed regardless of swelling. The mechanism for this intrinsic increase was not discussed in the published papers; however the increase in oxidation rates due to swelling was attributed to an increase in the reacting surface area of the specimen due to porosity.

\subsubsection{Oxidation of Uranium-Zirconium Alloys}

Only limited information is available on the oxidation of uranium-zirconium alloys. Waber (1958) performed a series of screening tests on binary uranium alloys; U-6w/oZr was identified in this study has having substantially lower oxidation rates in moist air (50\% RH) at $75^{\circ} \mathrm{C}$ than pure uranium, especially after water quenching from $850^{\circ} \mathrm{C}$ (Fig. 2). Less effect of 6 wt.\% zirconium additions was observed for as-cast alloys; no reason for the heat-treatment effect was identified. A similar effect of heat treatment on boiling water corrosion resistance of $\mathbf{U}-\mathrm{Zr}$ alloys was observed by Draley and Ruther (1953). Alloys for which $\mathrm{Zr}$ was retained in the $\alpha-U$ solid solution has greatly improved corrosion resistance compared to pure uranium or alloys where zirconium was present as $\mathrm{UZ}_{2}$ precipitate. Studies by Schnizlein et al. (1959) also demonstrated the greater oxidation resistance of $\mathrm{U}-\mathrm{Zr}$ alloys compared to uranium. At $200^{\circ} \mathrm{C}$ in oxygen the second stage oxidation rate was halved for a $\mathrm{U}-1.19 \mathrm{a} / \mathrm{oZr}$ alloy compared to uranium. This early information was later verified in 1993 by Matsui et al. (1993). Their tests on a U-20w/oZr alloy showed slower paralinear reaction rates than those for pure uranium as measured by Colmenares (1984) (Fig. 3). 
The mechanism by which zirconium slows oxidation in uranium has not been clearly identified. As observed in all of the above studies, zirconium does not preferentially form a protective oxide (as does chromium in stainless steels), nor does it substantially modify the $\mathrm{UO}_{2+x}$ reaction product. Matsui et al. (1993) suggested three possible factors for the decrease in rates for U-Zr compared to pure uranium: (1) a reduction in effective reacting uranium surface area by the presence of oxidation-resistant $\mathrm{UZr}_{2}$ precipitates; (2) a small reduction in oxygen pressure ( $2.1 \times 10^{4} \mathrm{~Pa}$ compared to $4.3 \times 10^{4} \mathrm{~Pa}$ ) relative to the study of pure uranium by Colmenares (1984) to which they compared their data; and (3) some effect of $\mathrm{Zr}$ in the $\alpha-U$ solid solution. Which of these mechanisms is the most likely was not identified. The findings of Draley and Ruther suggest that a solid solution effect may be important.

Cathcart (1972) identified changes in substrate creep strength as a significant contributor to increases in oxidation resistance of uranium alloys. The large difference in density between the oxide and the substrate creates large oxide and substrate stresses. Cathcart identified these stresses as the driving force for surface area increase of the specimen during oxidation at high temperature, leading to higher oxidation rates. Alloys which have greater creep strength will resist surface area increase and hence have lower oxidation rates. However, this mechanism is likely to be important only at higher temperatures (greater than $\sim 500^{\circ} \mathrm{C}$ ).

\subsubsection{Oxidation of Uranium-Plutonium Alloys}

Kelman, et al. (1965) reported on the oxidation properties of U-Pu and U$\mathrm{Pu}-\mathrm{X}$ alloys that was generated during the development of metallic fuels for zero-power fuels. Simple screening tests were performed on a number of alloys, both binary U-Pu alloys with Pu contents from 18 to 30 at.\% and ternary alloys with $\mathrm{Mo}, \mathrm{Fe}, \mathrm{Al}, \mathrm{C}, \mathrm{V}, \mathrm{Cu}$, and $\mathrm{Zr}$. Cylindrical specimens $6 \mathrm{~mm}$ in diameter and $6 \mathrm{~mm}$ long were exposed to a room temperature air environment for up to several months. The weight gain and time to disintegration were monitored. The U-Pu alloys were extremely susceptible to corrosion, with complete disintegration to powder occurring in a few as 6 days. The weight gain at the end of 120 days was approximately 15\%. For comparison, there was no measurable weight gain for the pure uranium specimen. Zirconium additions (of most relevance to ANL-W) significantly reduced the corrosion rate. A $2.1 \%$ weight gain was observed for the U-27a/oPu-6a/oZr alloy, with only partial disintegration. The poor corrosion resistance of U-Pu alloys was attributed to the presence of zeta phase; the reason for the poor resistance of zeta phase was not identified. 


\subsection{AQUEOUS CORROSION}

The corrosion behavior of uranium in aqueous solutions occurs via the same mechanisms as described above for saturated water vapor. The reaction of uranium with water occurs under anodic control to produce uranium dioxide. The diffusing species are again $\mathrm{OH}^{-}$ ions. The cathodic reaction is the reduction of water to produce $\mathrm{OH}^{-}$ions and hydrogen gas:

$$
\mathrm{H}_{2} \mathrm{O}+2 \mathrm{e}^{-} \rightarrow \frac{1}{2} \mathrm{H}_{2}+2 \mathrm{OH}^{-}
$$

while the anodic reaction is the oxidation of uranium (Tyfield, 1988). Wilkinson (1967) gives a simple relationship for the corrosion of uranium in oxygen-free water as a function of temperature:

$$
k=2.2 \times 10^{4} \exp \left[\frac{-5220}{R(\mathrm{cal} / \mathrm{mol} \cdot \mathrm{K}) T(\mathrm{~K})}\right] \frac{\mathrm{mg} \mathrm{U}}{\mathrm{cm}^{2} \cdot \mathrm{hr}}
$$

As with the reaction with water vapor, less than stoichiometric amounts of hydrogen gas are generated, with the remainder appearing in the form of a hydride, hydroxide, or hydrated oxide.

The presence of oxygen in the reacting water reduces the corrosion rate, due to the formation of a protective oxide film (Wilkinson, 1967); it is likely that a mechanism of corrosion inhibition by oxygen monolayer formation similar to that observed for gaseous oxidation is also operative.

\section{PYROPHORICITY}

\subsection{TEST METHODS}

Pyrophoricity refers to the tendency of certain metals to ignite and burn in a selfsustaining oxidation reaction. The pyrophoric nature of metals is usually defined in terms of an ignition temperature, which is the temperature at which a metal will ignite and burn in a selfsustained fashion for a given set of conditions. The temperatures achieved during burning can be extremely high $\left(>1500^{\circ} \mathrm{C}\right)$. Pyrophoric metals in powdered form represent an additional explosion danger due to high surface areas and therefore overall rates of reaction. Uranium and plutonium can both be pyrophoric in certain forms; early problems encountered with uranium were documented and analyzed by Smith (1956). 
The most common method used to characterize the pyrophoric tendencies of uranium and plutonium is the burning-curve method (Schnizlein et al., 1959). This technique is most often applied to solid specimens of varying geometries, although it has also been used with powders and fines (Tetenbaum et al., 1962). The specimen is heated at a controlled rate in a furnace containing an oxidizing atmosphere. Thermocouples are present both in the furnace for control purposes, and on or imbedded in the specimen. The specimen and furnace temperatures are recorded as a function of time; when the specimen ignites (i.e. the oxidation reaction becomes self-sustaining), the specimen temperature increases dramatically. The ignition temperature is determined as the temperature at which the specimen temperature deviates from the heating curve of the furnace. The design of the furnace and experimental set-up usually permits the ignition temperature to be determined as a function of gas composition, specimen geometry (specific area), and other variables.

Ignition temperatures can also be determined by the shielded-ignition test, which is similar to the burning curve test and utilizes a similar testing apparatus (Schnizlein et al., 1959). In this test the specimen is heated in the furnace to a specified temperature in an inert gas atmosphere. When the test temperature has been reached, an oxidizing atmosphere is admitted and the specimen temperature is recorded as a function of time. If the test temperature is higher than the specimen ignition temperature, the specimen will ignite with a corresponding dramatic increase in temperature. If the set furnace temperature is lower than the ignition temperature, self-heating due to oxidation, while still possible, will not be dramatic.

\subsection{IGNITION TEMPERATURES}

The ignition temperature is related to a balance of heat generated by the oxidation reaction and the heat lost through transfer to the surroundings. As temperature increases, the thermally activated oxidation rate, and hence heat production rate, increases dramatically. At some point the production of heat in the specimen greatly exceeds the rate at which it is lost to the surroundings, the reaction becomes self-sustaining, and ignition occurs. Factors which influence either the rate of heat generation or loss should influence the observed ignition temperature; Table III lists some possible factors. Of these, the most important variables for a given metal have been identified as: specific area (specimen area per unit mass), gas composition, and oxidation rate. The condition of the specimen prior to testing is also important. Prior oxidation and the presence of protective films or pyrophoric reaction products can influence the subsequent ignition temperature. 


\subsubsection{Effect of Specific Area}

Because oxidation is a surface reaction, the amount of area available for reaction is a critical factor in the determination of the heat generated in oxidation. Specific area is the best parameter to describe the effect of area, as it also accounts for the amount of material not reacting which can serve as a heat sink. Schnizlein et al. (1959) determined the effect of specific area for solid specimens on ignition temperatures determined by the burning curve method. With the exception of a few points in the $400-500^{\circ} \mathrm{C}$ range (which were attributed to the varying metallurgical histories of the specimens), the ignition temperature in oxygen was found to depend on specific area according to an Arrhenius-type relationship:

$$
S=6 \times 10^{-6} \exp \left[\frac{19,200}{R(\mathrm{cal} / \mathrm{mol} \cdot \mathrm{K}) T_{\mathrm{ig}}(\mathrm{K})}\right]
$$

where $S$ is the specific area in $\mathrm{cm}^{2} / \mathrm{g}$ and $T_{\mathrm{ig}}$ is the ignition temperature. Further studies, reported by Baker, Schnizlein, and Bingle (1966) showed that there was a deviation from Arrhenius-type behavior in ignition temperatures from $640^{\circ} \mathrm{C}$ to $315^{\circ} \mathrm{C}$ in oxygen similar to the that reported by Schnizlein (1959); these variations were associated by the authors with a change in oxide character from an autocatalytic to a self-protective form. Fig. 4 shows a plot of ignition temperatures in air and oxygen as a function of specific area.

Tetenbaum et al. (1962) performed burning curve experiments on powder samples of uranium and found a similar Arrhenius dependence on specific area. Fig. 5 shows a plot of ignition temperature versus specific area for the powder specimens. Both Schnizlein et al. (1959) and Tetenbaum et al. (1962) pointed out the importance of using the ignition temperature of the finest size particles (highest specific area) when determining the ignition temperature of an aggregate of different sized particles. The heat generated by the ignition of the finer particles was found to be sufficient to heat the larger particles to their ignition temperatures.

\subsubsection{Effect of Gas Composition}

The composition of the oxidizing gas also exerts a strong effect on the ignition behavior of uranium. The effect of oxygen concentration in $\mathrm{O}_{2}-\mathrm{N}_{2}$ and $\mathrm{O}_{2}-\mathrm{He}$ mixtures was reported by Schnizlein et al. (1959) and Baker, Schnizlein, and Bingle (1966). The effect of oxygen concentration in both mixtures on the ignition temperatures and maximum burning temperatures (the maximum temperature attained by the specimen during burning) of $8.5 \mathrm{~mm}$ cubes of uranium is shown in Fig. 6. The ignition temperatures for both mixtures are relatively constant 
for oxygen concentrations greater than $60 \%$. Below $60 \%$ the ignition temperatures increase; the increase for $\mathrm{O}_{2}-\mathrm{He}$ mixtures is greater and occur at higher oxygen concentrations than for $\mathrm{O}_{2}-\mathrm{N}_{2}$ mixtures. Burning temperatures decrease with decreasing oxygen concentrations for both mixtures; lower burning temperatures are observed in the $\mathrm{O}_{2}-\mathrm{He}$ mixtures. No explanations of the differences in behavior of the two mixtures were offered.

Despite its influence on low-temperature isothermal oxidation rates, the presence of saturated water vapor did not influence the ignition temperature of uranium. This is related to the fact that water vapor has little effect on oxidation rates above $200^{\circ} \mathrm{C}$, temperatures for which ignition occurs. Ignition experiments were also performed in carbon dioxide, but $8.5 \mathrm{~mm}$ uranium cubes did not ignite at temperatures up to $1000^{\circ} \mathrm{C}$.

\subsubsection{Ignition of Uranium-Zirconium Alloys}

Schnizlein et al. (1959) also reported on the ignition temperatures of a number of binary uranium alloys in $8.5 \mathrm{~mm}$ cube form. There was little change in ignition temperature for $\mathrm{U}-\mathrm{Zr}$ alloys compared to pure uranium for zirconium contents up to 1 at.\%. At a zirconium level of 2 at.\% the ignition temperature was lowered by $\sim 100^{\circ} \mathrm{C}$ to a value of $465^{\circ} \mathrm{C}$. The lower oxidation rate of higher zirconium content alloys would suggest that these alloys would have higher ignition temperatures; however this has not been verified experimentally.

\subsubsection{Ignition of Uranium-Plutonium Alloys}

The ignition behavior of some $\mathrm{U}-\mathrm{Pu}$ and $\mathrm{U}-\mathrm{Pu}-\mathrm{X}$ alloys was presented in a report by Schnizlein and Fischer (1964), and in a paper by Kelman, et al. (1965). The ignition temperatures of $6 \mathrm{~mm}$ diameter by $6 \mathrm{~mm}$ long cylinders were determined using the burning curve method. The ignition temperatures of U-Pu alloys (Pu contents between 18 and 30 at.\%) ranged from $157^{\circ} \mathrm{C}$ to $310^{\circ} \mathrm{C}$, compared to $716^{\circ} \mathrm{C}$ for pure uranium. A U-30Pu-6Zr (at.\%) alloy did not ignite during heating to $820^{\circ} \mathrm{C}$, although a significant amount of self heating of the specimen from $250^{\circ} \mathrm{C}$ to $500^{\circ} \mathrm{C}$ was observed. The drastically lowered igntion temperatures for the U-Pu alloys correlates well with their poor corrosion resistance.

\subsection{IGNITION MODELS}

Because ignition is essentially the result of an imbalance of heat generation and loss in the specimen, the process should be able to be modeled using thermodynamics and heat transfer 
principles. Such a model was developed by Baker, Schnizlein, and Bingle (1966) for the ignition of uranium. They balanced the heat generated by the exothermic oxidation reaction with the heat loss due to convection and radiation (conduction was assumed to be insignificant)-the balance of heat was converted to temperature changes in the specimen:

$$
C_{\mathrm{p}} \frac{\mathrm{d} T}{\mathrm{~d} t}=\frac{Q M_{\mathrm{U}} S}{10^{3} M_{\mathrm{O}_{2}}} \frac{\mathrm{d} w}{\mathrm{~d} t}-h S\left(T-T_{\mathrm{a}}\right)-\sigma \varepsilon S\left(T^{4}-T_{\mathrm{a}}^{4}\right)
$$

where

$$
\begin{array}{ll}
C_{\mathrm{p}} & =\text { specific heat of uranium }(0.044 \mathrm{cal} / \mathrm{g} \cdot \mathrm{K}) \\
T & =\text { metal temperature }(\mathrm{K}) \\
T_{\mathrm{a}} & =\text { furnace temperature }(\mathrm{K}) \\
t & =\text { time (min) } \\
Q & =\text { heat of reaction }(1089 \mathrm{cal} / \mathrm{g} \mathrm{U}) \\
M_{\mathrm{U}} & =\text { atomic mass of uranium }(238 \mathrm{~g} / \mathrm{mol}) \\
M_{\mathrm{O}_{2}} & =\text { molecular mass of oxygen }(32 \mathrm{~g} / \mathrm{mol}) \\
S & =\text { specific area }\left(\mathrm{cm}^{2} / \mathrm{g}\right) \\
w & =\text { quantity of oxygen reacted }\left(\mathrm{mg} / \mathrm{cm}^{2}\right) \\
h & =\text { heat transfer coefficient }\left(0.03 \mathrm{cal} / \mathrm{cm}^{2} \cdot \mathrm{K} \cdot \mathrm{min}\right) \\
\sigma & =\text { Stefan-Boltzmann constant }\left(8.16 \times 10^{-11} \mathrm{cal} / \mathrm{cm}^{2} \cdot \mathrm{min} \cdot \mathrm{K}^{4}\right) \\
\varepsilon & =\text { total emissivity of oxidized surface }(0.75)
\end{array}
$$

This equation was solved in a step-wise manner assuming an initial temperature of $300^{\circ} \mathrm{C}$, and using the isothermal oxidation rate data previously obtained for uranium (Schnizlein et al., 1959). The burning curves obtained using this model were found to accurately reflect the sharp break observed in ignition temperatures as a function of specific area shown on Fig. 4. Overall the predicted ignition temperatures were slightly higher than experimental values. This increase was attributed to the ability of the oxide formed to act as an insulating layer, thereby reducing heat losses. This factor was not accounted for in the model. Solbrig (1995) has repeated the calculations of this model using a linear oxidation rate law based on only the initial observed rate and does not report the existence of a break in the calculated curve.

Tetenbaum et al. (1962) modeled the ignition temperatures of uranium powder specimens using a modification of the Frank-Kamenetskii theory of gas explosions. The relation obtained using this model defined a critical condition above which no thermodynamic steady-state exists and an explosion (ignition) can occur. The critical condition is given by: 


$$
\delta=\frac{Q}{\lambda} \frac{E}{R T_{0}^{2}} r^{2} n A \exp \left[\frac{-E}{R T_{0}}\right]
$$

where

$\delta \quad=$ a geometry-specific dimensionless constant

$\lambda=$ thermal conductivity of the powder

$r \quad=$ the significant geometric dimension of the powder container

$Q \quad=$ heat of reaction

$n \quad=$ concentration (surface area of powder particles per unit volume)

$A \exp \left[\frac{-E}{R T_{0}}\right]=k$, the rate constant of the oxidation reaction

Ignition will occur when the right-hand side of the equation is greater than the value of $\delta$. Values of $\delta$ for different geometries have been computed. This relation was found to fairly accurately predict the ignition temperature of spherical uranium powder with an average diameter of $840 \mu \mathrm{m}$; a value of $325^{\circ} \mathrm{C}$ was calculated, compared to the actual value of $310^{\circ} \mathrm{C}$.

\section{IMPLICATIONS FOR STORAGE ISSUES}

The oxidation and ignition behavior of uranium and uranium-zirconium alloys has serious implications for storage problems. The most important fact that must be accounted for when considering storage options for uranium is the accelerated corrosion of uranium by water vapor in the absence of oxygen. This condition is commonly found in situations where uranium has been stored in sealed containers in an inert gas atmosphere. The atmosphere found in these containers usually contains some residual water vapor, which is present as an impurity in the inert gas, is generated by evaporation off of the stored material or packing material, or enters the container due to a poor seal. In any of these cases all of the water present in the container will react with the uranium; the reaction will occur relatively quickly due to the lack of inhibiting oxygen.

Solbrig et al. (1994) have postulated that the hydrogen present in the water molecules will eventually react in the closed container to form uranium dioxide and hydride via the reaction sequence:

$$
\begin{aligned}
& \mathrm{U}+2 \mathrm{H}_{2} \mathrm{O} \rightarrow \mathrm{UO}_{2}+2 \mathrm{H}_{2} \\
& 2 \mathrm{U}+3 \mathrm{H}_{2} \rightarrow 2 \mathrm{UH}_{3}
\end{aligned}
$$

This reaction sequence is a slight simplification of the expected situation in a closed container. The first reaction (eq. 23) will produce an oxide layer on the uranium, hydrogen gas in the container, 
and hydrogen at the metal-oxide interface. The interfacial hydrogen will react to form uranium hydride, or will diffuse to the oxide surface. When all of the water has been reacted the system will consist of uranium with an oxide coating (probably containing hydrides), and hydrogen gas. It is thermodynamically favorable for excess free hydrogen gas present in the container to react with the uranium to form uranium hydride according to equation 24 , but it must first be transported to the uranium, i.e. it must diffuse through the oxide coating. No information concerning the reaction of oxide-coated uranium with hydrogen gas was found in this literature survey.

The results of gas composition analyses of containers reported by Solbrig et al. where this type of accelerated corrosion has occurred verifies that not all of the hydrogen gas has reacted in the time of exposure. For all canisters the hydrogen gas content was higher than ambient air values, and in one case was greater than 13 vol. \%. This suggests that hydrogen does not react quickly with oxide-coated uranium at storage temperatures. In any case, the existence of free hydrogen gas in storage canisters creates a potentially explosive situation and is clearly undesirable. The situation is worsened by a third possible reaction, the oxidation of uranium hydride, which occurs if there is hydride present when air is re-admitted to the canister:

$$
2 \mathrm{UH}_{3}+2 \mathrm{O}_{2} \rightarrow 2 \mathrm{UO}_{2}+3 \mathrm{H}_{2}
$$

This reaction is rapid and exothermic; the heat generated could either ignite any hydrogen gas present in the container or the uranium itself.

The theoretically best solution to the problem of accelerated corrosion of uranium by water vapor in cans would be to store uranium under conditions of free-flowing dry air, as suggested by Waber (1958), to provide oxygen to inhibit the water-uranium reaction, and to prevent the accumulation of any hydrogen gas product. Unfortunately this appears to be impractical for the long-term storage of uranium, and especially uranium-containing spent nuclear fuel, because of the need for full containment of radioactive elements The use of oxygen to inhibit the reaction is also undesirable from the standpoint of uranium ignition. Oxygen gas concentrations considerably less than that found in air are needed to assure that ignition will not occur, especially for wastes which may contain powders or fines with high specific areas.

A resolution to this situation was suggested by Solbrig, et al. (1994), which is the use of a hydrogen getter in storage canisters to permanently remove any water or hydrogen. The getter is essentially an unsaturated hydrocarbon which has a strong affinity for hydrogen, which reacts to convert carbon triple bonds in the hydrocarbon to single bonds, thereby irreversibly removing free 
hydrogen from the system Palladium is used as a catalyst for the reaction and $\mathrm{LiH}$ is used to convert oxygen to water and water to hydrogen gas. This getter has been implemented in storage of some uranium-bearing materials at ANL-W and has so far been proven to be effective.

Another important factor to be considered for the long-term storage of uranium in fuel form is the post-irradiation condition of the fuel. If the fuel is metallic and has been irradiated to a high burnup with commensurate high swelling and increased surface area, the oxidation rates of the fuel will be considerably higher than the rates for unirradiated uranium, as described in section 1.2.3. Increasing surface area will also decrease ignition temperatures. This further verifies the need for detailed characterization of spent fuel before storage options and degradation rates can be determined.

The results presented for U-Zr alloys (commonly encountered at ANL-W) are inconclusive, however $\mathrm{Zr}$ does appear to have a beneficial effect on the oxidation behavior and certainly does not significantly degrade the oxidation resistance of uranium.

\section{PART II. PLUTONIUM}

\section{OXIDATION AND CORROSION}

\subsection{GASEOUS OXIDATION}

\subsubsection{Oxygen and Dry Air}

The oxidation behavior of plutonium is similar in many ways to that of uranium. Plutonium readily reacts with air at room temperature to form stoichiometric plutonium dioxide (Colmenares, 1975) according to the reaction

$$
\mathrm{Pu}+\mathrm{O}_{2} \rightarrow \mathrm{PuO}_{2}
$$

The information available on the oxidation rates of plutonium in dry air or oxygen is very limited, as most researchers have concentrated on determining reactions rates in oxygen-water vapor mixtures. The initial rates for the plutonium-dry air reaction have been characterized in terms of parabolic, linear, and paralinear kinetics. Final oxidation rates are generally reported as linear. 
Fig. 7 shows linear rate constants as a function of temperature for plutonium in pure oxygen or dry air environments. Considerable scatter in the data is evident, which can be attributed to the varying quality of the atmospheres (even small quantities of water present in the gas will have a significant effect on rates) and the purity of plutonium used in the studies. The differences between data obtained by Thompson (1965) and Schnizlein and Fischer (1963) are readily apparent. Thompson (1965) observed dramatic changes in oxidation rates at the allotropic transition temperatures, contrary to the findings of Schnizlein and Fischer (1963), who did not observe changes at transition temperatures. This difference has not been reconciled, as much of the later work on plutonium has focused on the behavior of $\delta$-stabilized alloys, discussed in section 1.1.3 below. An Arrhenius fit to the data shown in Fig. 7 can be described by the relation:

$$
k=6.6 \times 10^{8} \exp \left[\frac{-16,700}{R(\mathrm{cal} / \mathrm{mol} \cdot \mathrm{K}) T(\mathrm{~K})}\right] \frac{\mathrm{mg} \mathrm{Pu}}{\mathrm{cm}^{2} \cdot \mathrm{hr}}
$$

This relation has greatest validity in the temperature range $25 \leq T\left({ }^{\circ} \mathrm{C}\right) \leq 120^{\circ} \mathrm{C}$.

As mentioned above, the nominal reaction product formed at lower temperatures is $\mathrm{PuO}_{2}$. However, studies by Larson and Haschke (1981) have shown that in the very initial stages of plutonium reaction $\mathrm{Pu}_{2} \mathrm{O}_{3}$ is formed. Although $\mathrm{PuO}_{2}$ has the lowest standard free energy of formation per mole of plutonium, phase diagram considerations show that only $\mathrm{Pu}_{2} \mathrm{O}_{3}$ can coexist in contact with $\mathrm{Pu}$ metal at equilibrium (Haschke, 1992). The kinetics of the oxidation mechanism produce a final product which is mostly $\mathrm{PuO}_{2}$, with a layer of $\mathrm{Pu}_{2} \mathrm{O}_{3}$ existing at the $\mathrm{Pu}-\mathrm{PuO}_{2}$ interface. Exposure to vacuum at high temperatures results in the growth of $\mathrm{Pu}_{2} \mathrm{O}_{3}$ at the expense of $\mathrm{PuO}_{2}$. An early study by Terada et al. (1969) postulated the existence of plutonium monoxide, however later work by Larson and Haschke (1981) showed this compound to be a plutonium oxide carbide $\mathrm{PuO}_{x} \mathrm{C}_{y}$. Information on defect structures in plutonium oxides is very limited, as pointed out by Colmenares (1984). Defect structures in $\mathrm{PuO}_{2-x}$ were postulated by Manes et al. (1980) on the basis of a statistical thermodynamic study to consist of tetrahedral complexes of one oxygen vacancy bonded to two reduced cations.

Less information is available concerning the mechanism of oxidation of plutonium than for uranium, which is unfortunate as the mechanism appears to be much more complex due to the simultaneous formation of at least two oxides, $\mathrm{PuO}_{2}$ and $\mathrm{Pu}_{2} \mathrm{O}_{3}$. Stakebake et al (1993) report the formation of $\mathrm{PuO}_{3}$ during the reaction of $\mathrm{Pu}$ with water vapor between $250^{\circ} \mathrm{C}$ and $300^{\circ} \mathrm{C}$. Mass transport in the plutonium reaction with oxygen occurs, as with uranium, by the 
diffusion of oxygen anions through the oxide phases. As mentioned above, $\mathrm{Pu}_{2} \mathrm{O}_{3}$ is formed in the very initial stages of the oxidation process. Most of the $\mathrm{Pu}$ in $\mathrm{Pu}_{2} \mathrm{O}_{3}$ is subsequently oxidized to form $\mathrm{PuO}_{2}$, resulting in a multi-layer oxide structure of $\mathrm{PuO}_{2}, \mathrm{Pu}_{2} \mathrm{O}_{3}$, and $\mathrm{Pu}$. During the oxidation process a kinetic competition appears to exist between two different processes: the production of $\mathrm{Pu}_{2} \mathrm{O}_{3}$ from the plutonium-oxygen reaction and the oxidation of $\mathrm{Pu}_{2} \mathrm{O}_{3}$ to form $\mathrm{PuO}_{2}$. Oxygen ions which form $\mathrm{Pu}_{2} \mathrm{O}_{3}$ must diffuse through both oxide layers before reacting with plutonium. The kinetics of each reaction, and hence relative thicknesses of the oxides, are strongly influenced by temperature and atmosphere. Higher temperatures and lower oxygen pressures favor higher relative thicknesses of $\mathrm{Pu}_{2} \mathrm{O}_{3}$ in the multilayer structure, while lower temperatures and higher oxygen pressures favor higher relative thicknesses of $\mathrm{PuO}_{2}$.

\subsubsection{Water Vapor-Oxygen}

Although most work on plutonium has been performed using reactants containing some water vapor (intentionally added or not), unlike uranium few systematic studies have been performed on the plutonium-water vapor-oxygen system. The majority of the investigations were performed in the 1960 's by Raynor and Sackman at temperatures below $100^{\circ} \mathrm{C}$ (Sackman, 1960; Raynor and Sackman, 1963, 1965, 1967). The presence of moisture in air was found to dramatically increase the reaction rate. The variation of oxidation rate with humidity level in air at $90^{\circ} \mathrm{C}$ is shown in Fig. 8. Humidity levels below $2 \%$ are needed to significantly lower the oxidation rate. As with uranium, a plateau in reaction rate with respect to humidity level is observed from $2 \%$ to $80 \%$, with the rate increasing again above $80 \%$. Raynor and Sackman also observed that corrosion in moist inert gases occurs much more quickly than in moist air. An increase in rate of up to 25 times was observed for moist Ar compared to moist air at $25^{\circ} \mathrm{C}$ and $95 \%$ humidity.

The trends observed by Raynor and Sackman have been verified by other researchers. Schnizlein and Fischer (1967) reported increases of oxidation rates of 100 to 1000 times by saturation of the oxidizing atmosphere with moisture at temperatures below $100^{\circ} \mathrm{C}$. No effect of moisture was observed for temperatures greater than $200^{\circ} \mathrm{C}$. Stakebake and Steward (1972) also observed greater higher oxidation rates in moist atmospheres in dry air, but reported that the oxidation rate of a moist oxygen-nitrogen mixture was greater than the rate in a moist nitrogen gas at $90^{\circ} \mathrm{C}$. They claim that at $90^{\circ} \mathrm{C}$ there is little difference in reaction rates between moist air and moist inert gases, contrary to the situation at $25^{\circ} \mathrm{C}$. 
Researchers at Rocky Flats and Los Alamos have begun to systematically examine the reaction of plutonium with water vapor (Stakebake and Saba, 1990; Stakebake, 1992a; Stakebake et al., 1993). In the temperature regime of $200^{\circ} \mathrm{C}$ to $350^{\circ} \mathrm{C}$ reaction rates and activation energies of the plutonium-water reaction are reported to be very similar (Stakebake, 1992a), in agreement with the previous findings of Schnizlein and Fischer. Further work is being performed on the reaction at lower temperatures.

Plutonium dioxide is the principal product of the plutonium-water vapor reaction, although formation of $\mathrm{Pu}_{2} \mathrm{O}_{3}$ is also reported (Stakebake 1992a). As with uranium, the formation of several different hydrogen containing compounds has been postulated to account for a greater than stoichiometric weight gain, or less than stoichiometric $\mathrm{H}_{2}$ than that which would be expected according to the reaction:

$$
\mathrm{Pu}+2 \mathrm{H}_{2} \mathrm{O} \rightarrow \mathrm{PuO}_{2}+2 \mathrm{H}_{2}
$$

Waber (1958) and Raynor and Sackman (1967) have attributed the extra weight gain to adsorbed moisture in the form of hydrated plutonium oxides, $\mathrm{PuO}_{2} \cdot \mathrm{xH}_{2} \mathrm{O}$, where $x$ was observed to vary from 0.07 to $\mathbf{0 . 1 7}$. Waber also suggested the possibility of forming plutonium hydroxide compounds. Thompson (1965) and Stakebake $(1972,1992,1993)$ have reported the presence of plutonium hydride in the reaction products. As with uranium, the most recent studies provide very conclusive evidence for the presence of hydride as opposed to hydroxide or hydrated oxide.

The mechanism of plutonium oxidation by water vapor was reported by Waber (1958) to be similar to that found for uranium, i.e. the reaction is under anodic control, with hydroxide ions diffusing through the plutonium oxide layer. Later work by Stakebake and Saba (1990) examining the variation in reaction rates with water vapor pressures suggests that the reaction mechanism is very complex, with different mechanisms for different pressure ranges. On the basis of the observed pressure dependencies, they hypothesize that singly-charged oxygen ions $\left(\mathrm{O}^{-}\right)$are the diffusing species rather than $\mathrm{OH}^{-}$.

The reduction in reaction rates in atmospheres containing oxygen compared to those with inert gases is generally attributed to the formation of a protective oxide layer in oxygen (Raynor and Sackman, 1965). A mechanism involving the monolayer formation of adsorbed oxygen atoms on the oxide surface which block the adsorption of water molecules such as proposed for uranium is also conceivable. Thompson (1965) proposed a mechanism for hydride and hydroxide formation whereby plutonium hydride was an intermediate product in the 
reaction of plutonium with hydrogen to form plutonium hydroxide. Systematic work is still required for the $\mathrm{Pu}-\mathrm{H}_{2} \mathrm{O}-\mathrm{O}_{2}$ system.

\subsubsection{Oxidation of Plutonium Alloys}

The alloying of plutonium with either $\mathrm{Ga}, \mathrm{Zr}$, or $\mathrm{Al}$ to stabilize the cubic $\delta$ phase results in a substantial increase in corrosion resistance. These alloying additions have the most beneficial effects in moist air environments, as shown in Fig. 9, which shows the weight gains for several $\delta$-phase alloys in humid air at $35^{\circ} \mathrm{C}$. A principal difference between $\alpha$-phase plutonium and the $\delta$-phase alloys is that the alloys show parabolic growth kinetics while the unalloyed plutonium is more nearly linear. There appears to be less effect of alloying in dry air atmospheres; as shown in Fig. 10, there was little effect of $\mathrm{Ga}$ additions on the oxidation rates of plutonium in dry air at $75^{\circ} \mathrm{C}$. The principal benefit of $\delta$-phase alloys appears to be that they show similar rates of oxidation in dry and moist air, unlike plutonium which has much higher oxidation rates in moist air. The beneficial effect of these alloying additions does necessarily extend to moist inert gas environments. In a moist $\mathrm{Ar}$ atmosphere at $30^{\circ} \mathrm{C}, \mathrm{Pu}-3.3 \mathrm{a} / \mathrm{oGa}$ and $\mathrm{Pu}-1.1 \mathrm{a} / \mathrm{oAl}$ alloys showed higher oxidation rates than unalloyed plutonium (Raynor and Sackman, 1965). However, at a higher temperature of $60^{\circ} \mathrm{C}$ the situation was reversed; the alloys showed lower oxidation rates than the pure metal. The investigators did not suggest any explanation for this apparently anomalous behavior.

As with uranium alloys, examination of oxidation products for plutonium alloys does not reveal any preferential oxidation of the alloying elements. This is surprising because $\mathrm{Ga}, \mathrm{Zr}$, and $\mathrm{Al}$ would be expected to form more stable oxides than $\mathrm{Pu}$. The oxide formed on $\delta$-phase plutonium alloys is still primarily $\mathrm{PuO}_{2}$; Stakebake (1986) studied the oxidation of a $\mathrm{Pu}-1 \mathrm{wt} . \% \mathrm{Ga}$ alloy in dry air at higher temperatures $\left(150-400^{\circ} \mathrm{C}\right)$ and found only cubic $\mathrm{PuO}_{2}$, with no evidence of $\mathrm{Pu}_{2} \mathrm{O}_{3}$.

No mechanisms have been conclusively identified by any of the investigators for the increased oxidation resistance conferred by $\delta$-phase alloying additions. The first and most plausible explanation is that the $\delta$ phase is inherently more oxidation-resistant than the $\alpha$ phase. Oxidation rates in unalloyed plutonium decrease significantly in the temperature range at which the $\delta$ phase is stable $\left(325-450^{\circ} \mathrm{C}\right)$; reasons for this behavior have not been identified. Increased resistance to specimen breakup was reported by Raynor and Sackman (1965) to be an important contributing factor in the increased oxidation resistance of $\mathrm{Pu}-\mathrm{Al}$ and $\mathrm{Pu}-\mathrm{Ga}$ alloys. It is 
also conceivable that the absence of $\mathrm{Pu}_{2} \mathrm{O}_{3}$ in the oxidation product of $\mathrm{Pu}-\mathrm{Ga}$ alloys may somehow change the oxidation behavior. More information is needed concerning this subject.

\subsection{AQUEOUS CORROSION}

Published information available on the aqueous corrosion of plutonium is very limited. Studies on the corrosion of plutonium by distilled water and water containing various salts were performed at Rocky Flats in the 1980's (Haschke et al., 1983). Plutonium corrodes quickly in salt water; a one millimeter thick sheet of metal completely reacted in approximately 16 days. The reaction rates were found to be dependent on the concentration of anions in the corroding solution as shown in Fig. 11. An Arrhenius temperature dependence of the reaction rate in a one molar solution of $\mathrm{NiCl}_{2}$ was found:

$$
k=5.02 \times 10^{6} \exp \left[\frac{-5,150}{R(\mathrm{cal} / \mathrm{mol} \cdot \mathrm{K}) T(\mathrm{~K})}\right] \frac{\mathrm{mg} \mathrm{Pu}}{\mathrm{cm}^{2} \cdot \mathrm{hr}}
$$

The initial reaction product was found to be $\mathrm{PuOH}$. Upon consumption of all of the plutonium metal, $\mathrm{PuOH}$ further reacted in complex series of steps to eventually form $\mathrm{PuO}_{2}$. The conversion of $\mathrm{PuOH}$ to $\mathrm{PuO}_{2}$ took considerably longer than the initial reaction of $\mathrm{Pu}$ to form $\mathrm{PuOH}, \sim 450$ days compared to 16 days. The mechanism of aqueous corrosion was not specifically discussed in the report.

\section{PYROPHORICITY}

\subsection{IGNITION TEMPERATURES}

As with uranium, plutonium metal has the tendency to oxidize sufficiently rapidly at intermediate temperatures $\left(200-500^{\circ} \mathrm{C}\right)$ for self-heating and ignition to occur. This problem is of particular concern for forms which have a high specific area, such as lathe turnings, filings, and fine scrap from fuel element castings. Because of the radioactive and toxic nature of plutonium, considerable effort has been devoted to understanding its ignition behavior. The majority of tests involve the determination of ignition temperatures of specimens using the burning-curve method described in part I for uranium. 


\subsubsection{Effect of Specific Area}

Specific area has the strongest effect on the ignition temperatures of plutonium. Fig. 12 shows the variation of ignition temperatures with specific surface area in air and oxygen as determined by a number of researchers and compiled by Stakebake (1992b). There is a distinct transition between specimens which are essentially massive (specific areas less than 10 $\mathrm{cm}^{2} / \mathrm{g}$ ) and have ignition temperatures exceeding $450^{\circ} \mathrm{C}$, and those which are powders and fines (specific areas greater than $20 \mathrm{~cm}^{2} / \mathrm{g}$ ) and have ignition temperatures less than $200^{\circ} \mathrm{C}$. There is considerable scatter in the transition between the two regimes. The scatter is believed to be due to differing degrees of prior oxidation of the specimens, an effect which was later modeled by Martz et al. (1994) and is described below. As with uranium, the ignition temperature of a mixture of pieces or powders will be that of the piece which has the highest specific area, as heat from the ignition of finer pieces is usually sufficient to ignite the larger pieces.

\subsubsection{Effect of Gas Composition}

Musgrave (1971) investigated the effect of reduced oxygen gas concentration on the ignition and burning of plutonium. His results were dependent on specific area-for high specific area specimens there was no effect of oxygen concentrations above 1 vol.\% on ignition temperature. However, the maximum burning temperatures observed decreased continuously with oxygen concentration. The variances of ignition temperatures and maximum burning temperatures with oxygen concentration for plutonium filings are shown in Fig. 13. For massive coupons with low specific areas, reductions in oxygen concentrations below 6 vol.\% prevented ignition.

Musgrave also investigated the effects on ignition temperatures of certain solvent vapors (carbon tetrachloride and perchloroethylene) expected to be found in a laboratory environment. The presence of carbon tetrachloride $(10 \mathrm{vol} . \%)$ lowered the ignition temperature of plutonium lathe turnings from $270^{\circ} \mathrm{C}$ to $200^{\circ} \mathrm{C}$, while perchloroethylene vapor $(1.5 \mathrm{vol} . \%)$ had no effect on ignition temperatures.

A related study was performed by Felt (1967) to determine the extinguishing characteristics of plutonium fires. Plutonium samples were ignited using a welding arc, and attempts were then made to extinguish the fire using various techniques. Localized application of argon was effective in extinguishing fires, but only for fires burning in oxygen atmospheres containing less than 4 vol.\% oxygen. Other effective means of extinguishing 
plutonium fires were the application of magnesium oxide sand to the fire, and the removal of the burning piece(s) to a stainless steel or aluminum hood floor. As long as it remains intact, magnesium oxide sand acts to remove heat from the fire and insulate it from the oxidizing environment, while metal floors quickly conduct heat away from the fire.

\subsubsection{Effect of Prior Storage}

The effects of prior storage of plutonium samples in humid atmospheres on ignition temperature was investigated by Musgrave (1971). There was no effect of storage of up to 8 weeks in atmospheres containing up to $60 \%$ humidity for massive plutonium coupons. However, ignition temperatures of plutonium lathe turnings were significantly reduced by storage in humid atmospheres. Storage in an atmosphere containing $60 \%$ humidity for 6 weeks resulted in a decrease in ignition temperature from $350^{\circ} \mathrm{C}$ to $200^{\circ} \mathrm{C}$. This result was correlated with severe oxidation of the samples to a powder form, with fragmentation of the sample (higher specific area) and the possible presence of hydride contributing to the lower ignition temperature.

Pitts (1968) studied the effects of oxide coatings on plutonium ignition and found a steady decrease in ignition temperatures with prior oxidation time at $510^{\circ} \mathrm{C}$. The reductions in ignition temperatures were attributed to the formation of $\mathrm{PuO}$. The existence of $\mathrm{PuO}$ was later disproved by Larson and Haschke (1981), who postulated that $\mathrm{PuO}_{x} \mathrm{C}_{y}$ is formed instead. In either case, the re-oxidation of the monoxide (or monoxide carbide) upon subsequent heating in a burning-curve experiment provides heat to cause ignition at a lower furnace temperature. This concept was later modeled by Martz et al. (1994).

\subsubsection{Ignition of Plutonium Alloys}

The decreased oxidation rates of $\delta$-phase plutonium alloys would be expected to result in decreased ignition tendencies, i.e. higher ignition temperatures. The effects of various alloying additions on plutonium ignition temperatures was studied by Schnizlein and Fischer (1963). The effects of $\mathrm{Zr}$ and $\mathrm{Ga}$ were not studied, but additions of $\mathrm{Al}$ resulted in higher ignition temperatures for all specimens. The effect was much more marked at high specific areas. Fig. 14 is a summary plot showing the effects of alloying additions in 2 at.\% concentrations on ignition temperatures as a function of specific area. 


\subsection{IGNITION MODELS}

While it is possible to model the ignition behavior of plutonium using basic thermodynamic and heat transfer principles as was performed for uranium alloys by Baker, Schnizlein and Bingle (1966), such a model would be difficult to apply due to the more complex nature of the oxides formed. Martz et al. (1994) have developed a model which accounts for the nature of the oxide.

In this model they postulate that plutonium has an intrinsic ignition temperature of $475^{\circ} \mathrm{C}$. Massive samples must be externally heated to achieve this temperature, at which point selfheating and ignition occurs. For finely divided materials with higher specific area, they postulated that a two-step self-heating mechanism raises the temperature of the individual particles to $475^{\circ} \mathrm{C}$, at which point they ignite. Based on information concerning the nature of oxides products formed on plutonium as a function of temperature and oxygen concentration, they proposed that as the temperature is raised to near $150^{\circ} \mathrm{C}$ the $\mathrm{PuO}_{2}$ layer formed on the metal surface is self-reduced to $\mathrm{Pu}_{2} \mathrm{O}_{3}$ (as described in section 1.1.1). With further increases in temperature, the $\mathrm{Pu}_{2} \mathrm{O}_{3}$ is reoxidized to $\mathrm{PuO}_{2}$. This behavior was explained on the basis of a complex kinetic argument; for further details see Martz et al. (1994). The heat released by the oxidation reaction raises the temperature of the remaining plutonium metal to the intrinsic ignition temperature, with a measured ignition temperature of $150^{\circ} \mathrm{C}$.

A numerical model was developed to calculate the temperature increase of a given particle based on the heat released in the oxidation reaction. The model was developed for spherical and sheet geometries and predicted the variation in ignition temperatures due to several variables, including prior oxidation, heating rate, sample deformation, and alloying additions. An interesting aspect of this model is that no heat transfer was assumed to take place between the particle and the environment, directly in opposition to other models of ignition. The authors postulated that heat losses due to transfer were serendipitously balanced by irregularities in the sample geometry (perfect spheres and sheets were assumed in the calculation) which would produce greater oxide volume and hence heat.

\section{IMPLICATIONS FOR STORAGE ISSUES}

Although the information available on the oxidation of plutonium and plutonium alloys is more limited than that for uranium, the implications for the storage behavior of plutonium are very much the same. Plutonium degradation is theoretically best retarded by storing the metal in a 
freely-flowing dry air atmosphere. However, the need for material containment and accountability generally precludes storage in open environments. To avoid any accelerated oxidation by a water reaction and to limit the amount of reactants which have access to the stored plutonium, storage containers should incorporate double hermetic seals, which should be leak checked for integrity. Researchers at Los Alamos have found that even micron sized pinholes in the container permit sufficient access of oxygen and water vapor for significant degradation to occur in storage (Martz, 1995). Organic materials such as plastic wrappings must not be stored with plutonium, as hydrogen production due to radiolytic degradation of the organic material (by $\alpha$-particles) will react to form plutonium hydride. Experience has also shown that a small amount of hydride present in the plutonium corrosion product will catalyze the plutonium-oxygen reaction, giving rise to catastrophic oxidation rates (Hileman, 1994).

Plutonium presents the additional complication of the formation of $\mathrm{Pu}_{2} \mathrm{O}_{3}$ along with $\mathrm{PuO}_{2}$. The presence of this oxide complicates the mechanism of plutonium oxidation, which has not been fully clarified, especially with regard to the effects of moisture. Insufficient data exists to accurately predict oxidation rates of plutonium in a range of atmospheres, which creates difficulties in predicting the amounts of oxidation occurring in various storage environments. The possibility of formation of $\mathrm{Pu}_{2} \mathrm{O}_{3}$ or $\mathrm{PuO}_{x} \mathrm{C}_{y}$ is also an additional factor in consideration of the pyrophoricity hazards of stored plutonium. Plutonium previously exposed to conditions which favor the formation of these compounds will have lower ignition temperatures than unoxidized plutonium.

\section{CONCLUSIONS}

The following conclusions concerning the corrosion and pyrophoricity behavior of uranium and plutonium can be made:

- The reactions of uranium and plutonium with oxygen are similar. Both form stable oxides and react readily with air. The principal oxide formed at temperatures less than $300^{\circ} \mathrm{C}$ is $\mathrm{UO}_{2}$ or $\mathrm{PuO}_{2}$, although $\mathrm{Pu}_{2} \mathrm{O}_{3}$ is also formed in plutonium oxidation. Mass transport is accomplished by $\mathrm{O}^{2-}$ diffusion through the oxide.

- Addition of water vapor to the oxidizing gas increases the reaction rate for both metals. The highest gaseous oxidation rates are obtained in inert gas-water vapor atmospheres. Addition of oxygen to the $\mathrm{M}-\mathrm{H}_{2} \mathrm{O}$ system retards the reaction rate. 
This affect appears to be more pronounced for uranium. Both uranium and plutonium hydrides are formed in the water reaction in addition to oxide.

- $\quad$ Alloying with zirconium increases the oxidation resistance of both metals. Alloying of plutonium with other $\delta$-stabilizers such as gallium or aluminum also increases oxidation resistance.

- Similar ignition behavior is observed, with specific area of the sample exerting the greatest effect on measured ignition temperatures. Prior oxidation of plutonium to form $\mathrm{Pu}_{2} \mathrm{O}_{3}$ reduces subsequent ignition temperatures.

- The theoretical best storage environment is freely flowing dry air, however containment and accountability considerations preclude this option. Containers incorporating double hermetic seals and/or hydrogen-water getters should be used to limit the extent of oxidation. Organic seals and wrappings should be avoided.

\section{ACKNOWLEDGMENTS}

The author wishes to thank members of the Engineering Division and Technology Development Division, in particular R. G. Pahl, D. L. Porter, J. R. Krsul, and C. W. Solbrig, for comments and criticism of the document. D. C. Crawford deserves special recognition for his encouragement of this work, while J. L. Krieger gets extra thanks for her great assistance in obtaining many of the articles reviewed in this document.

\section{BIBLIOGRAPHY}

Baker, L., and J.D. Bingle (1986): The kinetics of oxidation of uranium between 300 and $625^{\circ} \mathrm{C}$. J, Nucl. Mater. 20, pp. 11-21.

Baker, L., L.G. Schnizlein, and J.D. Bingle (1966): The ignition of uranium. J. Nucl. Mater. 20 , pp. 22-38.

Baker, M.M., L.N. Less, and S. Orman (1966a): Uranium and water reaction. Part I - kinetics, products, and mechanism. Trans. Faraday Soc. 62, pp. 2513-2524.

Baker, M.M., L.N. Less, and S. Orman (1966b): Uranium + water reaction. Part II - effect of oxygen and other gases. Trans. of the Faraday Soc. 62, pp. 2525-2530. 
Bardon, M.F., and D.E. Fletcher (1983): Dust Explosions. Sci. Prog. Oxf. 68, pp. 459-473.

Bennett, M.J., B.L. Myatt and J.E. Antill (1974): The oxidation behaviour of highly irradiated uranium in dry carbon dioxide at $375-500^{\circ} \mathrm{C}$ and in dry air at $200-300^{\circ} \mathrm{C}$. J. Nucl. Mater. 50 , pp. 2-10.

Bennett, M.J., B.L. Myatt, D.R.V. Silvester, and J.E. Antill (1975): The oxidation behaviour of uranium in air at 50-300 ${ }^{\circ}$. J. Nucl. Mater. 57, pp. 221-236.

Bennett, M.J., and J.B. Price (1981): The oxidation behaviour of uranium in air at 348-765 K. J. Nucl. Mater. 101, pp. 44-55.

Bullock, J.S. (1976): Electrochemical studies of uranium alloy corrosion. Physical Metallurgy of Uranium Alloys (J.J. Burke, et al., eds.), Brook-Hill Publishing Co., pp. 847-895.

Cathcart, J.V. and G.F. Petersen (1972): The low-temperature oxidation of U-Nb and U-Nb-Zr alloys. J. Nucl. Mater 43, pp. 86-92.

Cathcart, J.V. (1974): Gaseous oxidation of uranium alloys. Physical Metallurgy of Uranium Alloys (J.J. Burke, et al., eds.), Brook Hill Publishing Company, pp. 775-813.

Chatfield, E.J. (1969): A semi-empirical analysis of the ignition behaviour of plutonium. J. Nucl. Mater. 32, pp. 218-227.

Colmenares, C.A. (1975): The oxidation of thorium, uranium, and plutonium. Prog. Solid State Chem. 9, pp. 139-239.

Colmenares, C.A. (1984): Oxidation mechanisms and catalytic properties of the actinides. Prog. Solid State Chem. 15, pp. 257-364.

Colmenares, C.A., R. Howell and T. McCreary (1981): Oxidation of Uranium Studied by Gravimetric and Positron-Annihilation Techniques. Lawrence Livermore National Laboratory Technical Report UCRL-85549.

Crawford, D.C. (1994): Personal communication.

Draley, J.E., J.W. McWhirter, F. Field and J. Guon (1953): The Corrosion of Low-Zirconium Uranium Alloys in Boiling Water. Argonne National Laboratory Technical Report ANL5030.

Felt, R.E. (1967): Burning and extinguishing characteristics of plutonium metal fires. Isochem, Inc. Technical Report ISO-756.

Gardner, E.R., T.L. Markin and R.S. Street (1965): The plutonium-oxygen phase diagram. J. Inorg. Nucl. Chem. 27, pp. 541-551.

Haschke, J.M. (1992): Hydrolysis of plutonium. Pluonium-oxygen phase diagram. Transuranium Elements (L.R. Morss and J. Fuger, eds.), American Chemical Society, pp. 416-425.

Haschke, J.M., A.E. Hodges, G.E. Bixby, and R.L. Lucas (1983): The Reaction of Plutonium with Water. Kinetic and Equilibrium Behavior of Binary and Ternary Phases in the Pu+O+H System. Rockwell International Rocky Flats Plant Technical Report RFP- 3416. 
Hileman, B. (1994): U.S. and Russia face urgent decisions on weapons plutonium. Chem. and Eng. News 72:24, pp. 12-25.

Kay, A.E. (1961): Some physicochemical properties of plutonium metal. The Metal Plutonium (A.S. Coffinberry and W.N. Miner, eds.), University of Chicago Press, pp. 183-193.

Kelman, L.R., H.V. Rhude, J.G. Schnizlein, and H. Savage (1965): Metallic plutonium for fast critical experiments. Plutonium 1965, A.E. Kay and M.B. Waldron, eds. (Chapman and Hall), pp. 510-524.

Kondo, T., E.D. Verink, F.H. Beck, and M.G. Fontana (1964): Gas chromatographic and gravimetric studies of uranium oxidation mechanism. Corrosion 20, pp. 314t-320t.

Kondo, T., F.H. Beck, and M.G. Fontana (1974): Corrosion 30, p. 330.

Krsul, J.R., and R. Villarreal (1990): ANL-W memorandum to L. Leibowitz.

Larson, D.T. (1980): AES and XPS study of plutonium oxidation. J. Vac. Sci. Technol. 17, pp. 55-58.

Larson, D.T., and J.M. Haschke (1981): XPS-AES characterization of plutonium oxides and oxide carbide. The existence of plutonium monoxide. Inorg. Chem. 20, pp. 1945-1950.

Leibowitz, L., J.G. Schnizlein, J.D. Bingle, and R.C. Vogel (1961): The kinetics of oxidation of uranium between $125^{\circ}$ and $250^{\circ} \mathrm{C}$. J. Electrochem. Soc. 108, pp. 1155-1160.

Longua, K.J. (1991): ANL memorandum, Examination of Bulged ZPPR Fuel Plate.

Martz, J.C. (1995): Personal communication.

Martz, J.C., J.M. Haschke, and J.L. Stakebake (1994): A mechanism for plutonium pyrophoricity. J. Nucl. Mater. 210, pp. 130-142.

Matsui, T., T. Yamada, Y. Ikai, and K. Naito (1993): Oxidation of U-20at\%Zr alloy in air at 4231063 K. J. Nucl. Mater. 199, pp. 143-148.

McGillivray, G.W., D.A. Geeson, and R.C. Greenwood (1994): Studies of the kinetics and mechanism of the oxidation of uranium by dry and moist air. A model for determining the oxidation rate over a wide range of temperatures and water vapour pressures. J. Nucl. Mater. 208, pp. 81-97.

Musgrave, L.E. (1971): Effect of water vapor, reduced oxygen concentrations, and solvent vapors on plutonium ignition. Dow Chemical Company Rocky Flats Division Technical Report RFP1566.

Musgrave, L.E. (1972): A theory of burning curve ignition of nuclear materials. J. Nucl. Mater. 43 , pp. $155-163$.

Naito, K., T. Tsuji, T. Matsui, T. Fujino, T. Yamashita and K. Ohuchi (1992): Defect chemistry of plutonium oxides. Transuranium Elements - A Half Century (L.R. Morss and J. Fuger, eds.), American Chemical Society, pp. 440-448. 
Newton, A.S., J.C. Warf, F.H. Spedding, O. Johnson, I.B. Johns, R.W. Nottorf, J.A. Ayres, R.W. Fisher, and A. Kant (1949): Uranium hydride - II. Radiochemical and chemical properties. Nucleonics pp. 17-25.

Orman, S. (1963): The effect of certain gases on the rate of oxidation of uranium by water vapour. Chemistry and Industry pp. 1692-1693.

Orman, S. (1974): Oxidation of Uranium and Uranium Alloys. Physical Metallurgy of Uranium Alloys (J.J. Burke, et al., eds.), Brook Hill Publishing Company, pp. 815-833.

Orman, S., and R. Robertson (1965): A novel method for investigating metal-water reactions. Chemistry and Industry pp. 1905-1907.

Pearce, R.J., M.J. Bennett, and J.B. Price (1988): Oxidation of irradiated uranium in moist air. Nucl. Energy 27, pp. 305-309.

Pitts, S.H. (1968): Factors influencing the ignition of metallic plutonium. Nuclear Safety 9, pp. 112-119.

Raynor, J.B., and J.F. Sackman (1963): Oxidation of plutonium in moist air and argon. Nature 197, pp. 587-588.

Raynor, J.B., and J.F. Sackman (1965): Some observations on the oxidation of unalloyed and $\delta$ stabilized plutonium metal. Plutonium 1965 (A.E. Kay, et al., eds.), Chapman and Hall, pp. 575-591.

Raynor, J.B., and J.F. Sackman (1967): The atmospheric oxidation of unalloyed plutonium at low humidities. J. Nucl. Mater. 23, pp. 302-308.

Ritchie, A.G. (1981): A review of the rates of reaction of uranium with oxygen and water vapour at temperatures up to $300^{\circ} \mathrm{C}$. J. Nucl. Mater. 102, pp. 170-182.

Ritchie, A.G. (1984a): The kinetics and mechanism of the uranium-water vapour reaction - an evaluation of some published work. J. Nucl. Mater. 120, pp. 143-153.

Ritchie, A.G. (1984b): The kinetics of the initial stages of the reaction of uranium with oxygen. $J$. of the Less Common Metals 98, pp. 193-214.

Ritchie, A.G., R.C. Greenwood, and S.J. Randles (1989): The kinetics of the uranium-oxygenwater vapour reaction between 40 and $100^{\circ} \mathrm{C}$. J. Nucl. Mater. 139, pp. 121-136.

Sackman, J.F. (1960): The atmospheric oxidation of plutonium metal. Plutonium 1960 (E. Grison, et al., eds.), Cleaver-Hume Press, pp. 222-229.

Schnizlein, J.G., L. Baker and J.D. Bingle (1966): The ignition of binary alloys of uranium. $J$. Nucl. Mater. 20, pp. 39-47.

Schnizlein, J.G., and D.F. Fischer (1963): Isothermal Oxidation of Plutonium: in Chemical Engineering Division Quarterly Report. Argonne National Laboratory Technical Report ANL6687.

Schnizlein, J.G., and D.F. Fischer (1963): Plutonium Ignition Studies: in Chemical Engineering Division Summary Report. Argonne National Laboratory Technical Report ANL-6725. 
Schnizlein, J.G., and D.F. Fischer (1964): Plutonium Oxidation and Ignition Studies: in Chemical Engineering Division Semiannual Report. Argonne National Laboratory Technical Report ANL-6800.

Schnizlein, J.G. and D.F. Fischer (1967): The kinetics of oxidation of plutonium metal and a plutonium-3.4 a/o aluminum alloy at temperatures from $140^{\circ}$ to $550^{\circ} \mathrm{C}$. J. Electrochem. Soc. 114, pp. 23-29.

Schnizlein, J.G. and D.F. Fischer (1968): Ignition behavior of plutonium metal and certain binary alloys. J. Electrochem. Soc. 115, pp. 462-466.

Schnizlein, J.G., P.L. Pizzolato, H.A. Porte, J.D. Bingle, D.F. Fischer, L.W. Mishler, and R.C. Vogel (1959): Ignition Behaviour and Kinetics of Oxidation of the Reactor Metals, Uranium, Zirconium, Plutonium, and Thorium, and Binary Alloys of Each. Argonne National Laboratory Technical Report ANL-5974.

Sliva, M. (1992): An assesment of the flammability and explosion potential of defense transuranic waste. Nuclear Safety 33, pp. 220-228.

Smith, R.B. (1956): The Fire Properties of Metallic Uranium (TID-8011), Technical Information Service - Atomic Energy Commission.

Solrig, C.W. (1995): Personal communication.

Solbrig, C.W., J.R. Krsul, and D.N. Olsen (1994): Pryophoricity of uranium in long-term storage environments. DOE Spent Nuclear Fuel - Challenges and Initiatives, American Nuclear Society, pp. 89-93.

Spedding, F.H., A.S. Newton, J.C. Warf, O. Johnson, R.W. Nottorf, I.B. Johns, and A.H. Daane (1949): Uranium hydride - I. Preparation, composition, and physical properties. Nucleonics pp. 4-16.

Stakebake, J.L. (1971): The storage behavior of plutonium metal, alloys, and oxide. J. Nucl. Mater. 38, pp. 241-259.

Stakebake, J.L. (1980): Kinetics for the hydriding of a plutonium-1w/o gallium alloy powder. $J$. Vac. Sci. Technol. 17, pp. 114.

Stakebake, J.L. (1981): Kinetic studies of the reaction of plutonium hydride with oxygen. Nucl. Sci. and Eng. 78, pp. 386-392.

Stakebake, J.L. (1986): Atmospheric oxidation of Pu-1wt.\%Ga in the temperature range 150$500^{\circ} \mathrm{C}$. J. of the Less Common Metals 123, pp. 185-197.

Stakebake (1992a): Characterization of the plutonium-water reaction. Reaction kinetics between 200 and $350^{\circ}$ C. Transuranium Elements (L.R. Morss and J. Fuger, eds.), pp. 251-259.

Stakebake, J.L. (1992b): Plutonium Pyrophoricity. EG\&G Rocky Flats Plant Technical Report RFP-4517.

Stakebake, J.L., D.T. Larson, and J.M. Hascke (1993): Characterization of the Plutonium-Water Reaction Part II: Formation of a Binary Oxide Containing Pu(IV). Los Alamos National Laboratory Technical Report LA-UR-93-0040. 
Stakebake, J.L., and L.A. Lewis (1987): Oxidation of plutonium-1wt\% gallium in nitrogen/5.5\% oxygen mixtures. J. Nucl. Mater. 148, pp. 115-120.

Stakebake, J.L., and L.A. Lewis (1988): The kinetics and oxygen pressure dependence of the high temperature oxidation of Pu-1wt.\%Ga. J. Less Common Metals 136, pp. 349-366.

Stakebake, J.L., and M.A. Saba (1990): Reaction kinetics for the high temperature oxidation of $\mathrm{Pu}-1$ wt.\%Ga in water vapor. J. Less Common Metals 158, pp. 221-237.

Stakebake, J.L., and L.M. Steward (1972): Plutonium oxidation in moist oxygen-nitrogen mixtures. J. Electrochem. Soc. 119, pp. 730-735.

Tanon, A., and H. Bordes-Pagés (1965): Oxidation measurements on a-plutonium in various glovebox atmospheres. Plutonium 1965 (A.E. Kay, et al., eds.), Chapman and Hall, pp. 603-622.

Terada, K., R.L. Meisel, and M.R. Dringman (1969): High temperature x-ray investigation of plutonium oxidation. J. Nucl. Mater. 30, pp. 340-342.

Tetenbaum, M., L. Mishler, and G. Schnizlein (1962): Uranium powder ignition studies. Nucl. Sci. and Eng. 14, pp. 230-238.

Thompson, M.A. (1965): Observations on the atmospheric oxidation of plutonium metal. Plutonium 1965 (A.E. Kay, et al., eds.), Chapman and Hall, pp. 592-602.

Thompson, M.A. (1966): The oxidation and ignition of plutonium. Dow Chemical Company Rocky Flats Division Technical Report RFP-491.

Tsoulfandis, N., and R.G. Cochran (1991): Radioactive waste management. Nucl. Tech. 93, pp. 263-304.

Tyfield, S.J. (1988): Corrosion of reactor grade uranium in aqueous solutions relevant to storage and transport. Nucl. Energy 27, pp. 91-98.

Villarreal, R., and J.R. Krsul (1990): ANL memorandum to L. Leibowitz.

Waber, J.T. (1952): A review of the corrosion of uranium and its alloys. Los Alamos National Laboratory Technical Report LA-1524.

Waber, J.T. (1958): The corrosion behavior of plutonium and uranium. 2nd U.N. International Conference on Peaceful Uses of Atomic Energy, pp. 204-214.

Waber, J.T., and E.S. Wright (1961): The corrosion of plutonium. The Metal Plutonium (A.S. Coffinberry and W.N. Miner, eds.), University of Chicago Press, pp. 194-204.

Waber, J.T. (1967): Corrosion and oxidation. Plutonium Handbook (O.J. Wick, ed.), The American Nuclear Society, pp. 145-189.

Weirick, L.J. (1984): The Oxidation of Uranium in Low Partial Pressures of Oxygen and Water Vapor at $100^{\circ} \mathrm{C}$. Sandia National Laboratory Report SAND83-0618.

Wilkinson, W.D. (1962): Uranium Metallurgy, Interscience Publishers. 
Winer, K., C.A. Colmenares, R.L. Smith, and F. Wooten (1983): Interaction of water vapor with clean and oxygen-covered uranium surfaces. Surface Science 183, pp. 67-99.

Wood, D.H., S.A. Snowden, H.J. Howe, L.L. Thomas, D.W. Moon, H.R. Gregg, and P.E. Miller (1994): Regarding the chemistry of metallic uranium stored in steel drums. J. Nucl. Mater. 209, pp. 113-115.

Zima, G.E. (1960): Pyrophoricity of uranium in reactor environments. Hanford Atomic Products Operation Technical Report HW-62442. 
TABLE I. Summary Table for Uranium Reaction with Dry Air/ $\mathrm{O}_{2}$

\begin{tabular}{|c|c|c|c|c|c|c|}
\hline Reference & $\begin{array}{l}\text { Metal Type; } \\
\text { Impurities }\end{array}$ & Environment & $\begin{array}{c}\text { Temperature } \\
\text { Range }\end{array}$ & $\begin{array}{l}\text { Kinetic } \\
\text { Behavior }\end{array}$ & $\begin{array}{c}\text { Rate } \\
\text { Equations }\end{array}$ & $\begin{array}{l}\text { Reaction } \\
\text { Products }\end{array}$ \\
\hline $\begin{array}{l}\text { Schnizlein et al. } \\
\text { (1959) }\end{array}$ & $\begin{array}{l}\text { U; } \\
\text { C: } 21 \mathrm{ppm} \\
\text { N: } 56 \mathrm{ppm} \\
\text { Si: } 40 \mathrm{ppm} \\
\text { Fe: } 45 \mathrm{ppm} \\
\text { Ni: } 15 \mathrm{ppm}\end{array}$ & $\begin{array}{l}\mathrm{O}_{2} \\
\text { Pressures (Torr): } \\
20 \\
50 \\
200 \\
500 \\
\\
20 \\
50 \\
200 \\
500\end{array}$ & $125-295^{\circ} \mathrm{C}$ & Two stage linear & $\begin{array}{l}\text { Initial linear stage: } \\
k=1.02 \times 10^{4} \exp (-6230 / T(\mathrm{~K})) \\
k=1.44 \times 10^{4} \exp (-6330 / T(\mathrm{~K})) \\
k=3.18 \times 10^{4} \exp (-7500 / T(\mathrm{~K})) \\
k=1.86 \times 10^{4} \exp (-9400 / T(\mathrm{~K})) \\
\text { Einal linear stage: } \\
k=1.20 \times 10^{7} \exp (-8440 / T(\mathrm{~K})) \\
k=8.40 \times 10^{7} \exp (-9150 / T(\mathrm{~K})) \\
k=6.00 \times 10^{8} \exp (-10000 / T(\mathrm{~K})) \\
k=1.26 \times 10^{9} \exp (-10300 / T(\mathrm{~K})) \\
\mathrm{mg} / \mathrm{cm}^{2} \cdot \mathrm{hr}\end{array}$ & $\mathrm{UO}_{2}$ \\
\hline $\begin{array}{l}\text { Liebowitz et al. } \\
\text { (1961) }\end{array}$ & $\begin{array}{l}\mathrm{U} ; \\
\mathrm{C}: 21 \mathrm{ppm} \\
\mathrm{N}: 56 \mathrm{ppm} \\
\text { Si: } 40 \mathrm{ppm} \\
\text { Fe: } 45 \mathrm{ppm} \\
\text { Ni: } 15 \mathrm{ppm}\end{array}$ & $\overline{\mathrm{O}_{2}}$ & $125-250^{\circ} \mathrm{C}$ & Two stage linear & $\begin{array}{l}\text { Initial linear stage: } \\
k=8.88 \times 10^{4} P^{1 / n} \exp (-5380 / T(\mathrm{~K})) \\
\mathrm{mg} / \mathrm{cm}^{2} \cdot \mathrm{hr} \\
1 / n \text { varies with } T \text { from } 1 / 1.11 \text { to } \\
1 / 3.85\end{array}$ & $\mathrm{UO}_{2}$ \\
\hline $\begin{array}{l}\text { Bennett and Price } \\
\text { (1981) }\end{array}$ & $\begin{array}{l}\text { U; } \\
\text { Al: } 1200 \mathrm{ppm} \\
\text { Fe: } 310 \mathrm{ppm}\end{array}$ & Dry air & $50-450^{\circ} \mathrm{C}$ & Linear & $\begin{array}{l}k=6.12 \times 10^{6} \exp (-8610 / T(\mathrm{~K})) \\
\mathrm{mg} / \mathrm{cm}^{2} \cdot \mathrm{hr}\end{array}$ & $\begin{array}{l}\text { Not specifically } \\
\text { mentioned. }\end{array}$ \\
\hline $\begin{array}{l}\text { Colmenares et al. } \\
\text { (1981) }\end{array}$ & $\begin{array}{l}\mathrm{U} ; \\
\text { C: } 19 \mathrm{ppm} \\
\mathrm{N}: 17 \mathrm{ppm} \\
\text { O: } 18 \mathrm{ppm} \\
\text { (97 ppm total) }\end{array}$ & $\begin{array}{l}\mathrm{O}_{2:} \\
47-313 \text { Torr }\end{array}$ & $120-177^{\circ} \mathrm{C}$ & $\begin{array}{l}\text { Paralinear: } \\
\Delta \mathrm{W} / \mathrm{A}=k r^{0.8}+C\end{array}$ & $\begin{array}{l}k=2.95 \times 10^{7} \exp (-8540 / T(\mathrm{~K})) \\
\mathrm{mg} / \mathrm{cm}^{2} \cdot \mathrm{hr}^{0.8} \\
\text { No pressure dependence. }\end{array}$ & $\mathrm{UO}_{2.22}$ \\
\hline
\end{tabular}


TABLE I. Summary Table for Uranium Reaction with Dry Air/ $\mathrm{O}_{2}$ (Contd)

\begin{tabular}{|c|c|c|c|c|c|c|}
\hline Reference & $\begin{array}{l}\text { Metal Type; } \\
\text { Impurities }\end{array}$ & Environment & $\begin{array}{c}\text { Temperature } \\
\text { Range }\end{array}$ & $\begin{array}{l}\text { Kinetic } \\
\text { Behavior }\end{array}$ & $\begin{array}{c}\text { Rate } \\
\text { Equations }\end{array}$ & $\begin{array}{l}\text { Reaction } \\
\text { Products }\end{array}$ \\
\hline $\begin{array}{l}\text { Ritchie } \\
\text { (1981) }\end{array}$ & $\bar{U}$ & $\mathrm{O}_{2} /$ dry air & $40-300^{\circ} \mathrm{C}$ & Linear & $\begin{array}{l}\text { Best fit to available literature: } \\
k=6.9 \times 10^{8} \exp (-9150 / T(\mathrm{~K})) \\
\mathrm{mg} / \mathrm{cm}^{2} \cdot \mathrm{hr}\end{array}$ & N/A \\
\hline $\begin{array}{l}\text { Weirick } \\
\text { (1984) }\end{array}$ & $\begin{array}{l}\text { U; } \\
\text { C: } 19 \mathrm{ppm} \\
\mathrm{N}: 17 \mathrm{ppm} \\
\text { O: } 18 \mathrm{ppm} \\
\text { (100 ppm total) }\end{array}$ & $\begin{array}{l}\mathrm{O}_{2}: \\
\text { Varying pressure }\end{array}$ & $100^{\circ} \mathrm{C}$ & Linear & $\begin{array}{l}k=8 \times 10^{-4} \mathrm{mg} / \mathrm{cm}^{2} \cdot \mathrm{hr} \\
\text { No pressure dependence. }\end{array}$ & $\mathrm{UO}_{2.2}$ \\
\hline $\begin{array}{l}\text { McGillivray et al. } \\
\text { (1994) }\end{array}$ & $\begin{array}{l}\mathrm{U} ; \\
\mathrm{Fe}, \mathrm{C}, \mathrm{Ni}, \mathrm{Al} \\
\text { (<100 ppm total) }\end{array}$ & Dry air & $40-350^{\circ} \mathrm{C}$ & $\begin{array}{l}\text { Parabolic to } 1 \mu \mathrm{m} \\
\text { oxide growth, } \\
\text { then linear. }\end{array}$ & $\begin{array}{l}\text { Linear: } \\
k=3.94 \times 10^{6} \exp (-8077 / \mathrm{T}(\mathrm{K})) \\
\mathrm{mg} / \mathrm{cm}^{2} \cdot \mathrm{hr} \\
\text { Parabolic not reported. }\end{array}$ & $\mathrm{UO}_{2}$ \\
\hline
\end{tabular}


TABLE II. Summary Table for Uranium Reaction with Water Vapor

\begin{tabular}{|c|c|c|c|c|c|c|}
\hline Reference & $\begin{array}{l}\text { Metal Type; } \\
\text { Impurities }\end{array}$ & Environment & $\begin{array}{c}\text { Temperature } \\
\text { Range }\end{array}$ & $\begin{array}{l}\text { Kinetic } \\
\text { Behavior }\end{array}$ & $\begin{array}{c}\text { Rate } \\
\text { Equations }\end{array}$ & $\begin{array}{l}\text { Reaction } \\
\text { Products }\end{array}$ \\
\hline $\begin{array}{l}\text { Orman } \\
(\mathbf{1 9 6 3 )}\end{array}$ & $\begin{array}{l}\text { U; } \\
\text { Impurity levels } \\
\text { not given. }\end{array}$ & $\begin{array}{l}\text { Base gas: } \\
\mathrm{H}_{2} \mathrm{O} \text { (vapor) at a } \\
\text { pressure of } 233 \\
\text { Torr. } \\
\text { Additions: } \\
\mathrm{N}_{2}: \text { 6-150 Torr } \\
\\
\mathrm{H}_{2}: 3-10 \text { Torr } \\
\\
\mathrm{O}_{2}: \\
5.5 \text { Torr } \\
51 \text { Torr } \\
150 \text { Torr }\end{array}$ & $70^{\circ} \mathrm{C}$ & Linear & $\begin{array}{l}\text { Base gas: } \\
k=0.31 \mathrm{mg} / \mathrm{cm}^{2} \cdot \mathrm{hr} \\
\text { Additions: } \\
\mathrm{N}_{2}: \\
k=0.34 \mathrm{mg} / \mathrm{cm}^{2} \cdot \mathrm{hr} \\
\mathrm{H}_{2}: \\
k=0.33 \mathrm{mg} / \mathrm{cm}^{2} \cdot \mathrm{hr} \\
\mathrm{O}_{2}: \\
k=0.36 \mathrm{mg} / \mathrm{cm}^{2} \cdot \mathrm{hr}(5.5 \mathrm{~mm} \mathrm{Hg}) \\
k=0.20 \mathrm{mg} / \mathrm{cm}^{2} \cdot \mathrm{hr}(51 \mathrm{~mm} \mathrm{Hg}) \\
k=0.017 \mathrm{mg} / \mathrm{cm}^{2} \cdot \mathrm{hr}(150 \mathrm{~mm} \mathrm{Hg})\end{array}$ & $\begin{array}{l}\text { Not specifically } \\
\text { mentioned. }\end{array}$ \\
\hline $\begin{array}{l}\text { Kondo et al. } \\
\text { (1964) }\end{array}$ & $\begin{array}{l}\text { U; } \\
\text { Fe: } 20 \mathrm{ppm} \\
\text { Cu: } 20 \mathrm{ppm} \\
\text { Ni: } 20 \mathrm{ppm} \\
\text { C: } 18 \mathrm{ppm}\end{array}$ & $\begin{array}{l}\text { Moist } \mathrm{N}_{2}: \\
33 \text { Torr } \mathrm{H}_{2} \mathrm{O}\end{array}$ & $60-120^{\circ} \mathrm{C}$ & $\begin{array}{l}\text { Initially } \\
\Delta W \propto t^{1.5} \\
\text { later parabolic. }\end{array}$ & $\begin{array}{l}k \propto \exp (-5025 / T(\mathrm{~K})) \\
\text { pre-exponential factor not given. }\end{array}$ & $\begin{array}{l}\mathrm{UO}_{2} ; \\
\mathrm{UH}_{3} \text { as } \\
\text { intermediate } \\
\text { reaction product. }\end{array}$ \\
\hline $\begin{array}{l}\text { Baker et al. } \\
\text { (1966a) }\end{array}$ & $\begin{array}{l}\text { U; } \\
\text { Fe: } 98 \mathrm{ppm} \\
\text { Si: } 17 \mathrm{ppm} \\
\text { Al: } 15 \mathrm{ppm} \\
\text { C: } 150 \mathrm{ppm}\end{array}$ & $\mathrm{H}_{2} \mathrm{O}$ (vapor) & $35-100^{\circ} \mathrm{C}$ & Linear & No explict rate relations given. & $\begin{array}{l}\mathrm{UO}_{2+x}, 0<x<0.1 \\
\mathrm{UH}_{3}(2-9 \% \text { of } \mathrm{U} \\
\text { in product). }\end{array}$ \\
\hline $\begin{array}{l}\text { Baker et al. } \\
\text { (1966b) }\end{array}$ & $\begin{array}{l}\text { U; } \\
\text { Fe: } 98 \mathrm{ppm} \\
\text { Si: } 17 \mathrm{ppm} \\
\text { Al: } 15 \mathrm{ppm} \\
\text { C: } 150 \mathrm{ppm}\end{array}$ & $\mathrm{H}_{2} \mathrm{O}$ (vapor) $+\mathrm{O}_{2}$ & $90-110^{\circ} \mathrm{C}$ & $\begin{array}{l}\text { Initally } \\
\text { parabolic, then } \\
\text { linear. }\end{array}$ & $\begin{array}{l}\text { No explicit rate equations given. } \\
\text { Oxygen strongly retarded reaction } \\
\text { (by a factor of } 30-100 \text { ). }\end{array}$ & $\begin{array}{l}\mathrm{UO}_{2.2} \text { to } \mathrm{UO}_{2.4} \\
\mathrm{UO}_{3} \cdot 0.8 \mathrm{H}_{2} \mathrm{O} \text { (at } \\
100 \% \text { R.H.). }\end{array}$ \\
\hline
\end{tabular}


TABLE II. Summary Table for Uranium Reaction with Water Vapor (Contd)

\begin{tabular}{|c|c|c|c|c|c|c|}
\hline Reference & $\begin{array}{c}\text { Metal Type; } \\
\text { Impurities } \\
\end{array}$ & Environment & $\begin{array}{c}\text { Temperature } \\
\text { Range }\end{array}$ & $\begin{array}{l}\text { Kinetic } \\
\text { Behavior }\end{array}$ & $\begin{array}{c}\text { Rate } \\
\text { Equations } \\
\end{array}$ & $\begin{array}{l}\text { Reaction } \\
\text { Products }\end{array}$ \\
\hline $\begin{array}{l}\text { Kondo et al. } \\
(1974)\end{array}$ & $\begin{array}{l}\mathrm{U} ; \\
\mathrm{Fe}: 20 \mathrm{ppm} \\
\mathrm{Cu}: 20 \mathrm{ppm} \\
\mathrm{Ni}: 20 \mathrm{ppm} \\
\mathrm{C}: 18 \mathrm{ppm}\end{array}$ & $\begin{array}{l}\text { Moist } \mathrm{Ar}: \\
83 \text { Torn } \mathrm{H}_{2} \mathrm{O} \\
\text { Moist } \mathrm{He}: \\
83 \text { Torn } \mathrm{H}_{2} \mathrm{O} \\
\\
\text { Addition of } \sim 0.15 \\
\text { vol. \% } \mathrm{O}_{2} \text { to } \\
\text { above. }\end{array}$ & $65-80^{\circ} \mathrm{C}$ & $\begin{array}{l}\text { Moist inert_gas } \\
\text { Three stages: } \\
\text { I. logarithmic } \\
\text { II. } W \propto t^{1.5} \\
\text { III. linear } \\
\text { Oxygen addition } \\
\text { Linear, then } \\
\text { parabolic. }\end{array}$ & $\begin{array}{l}\text { None given for moist } \mathrm{Ar} \text { and } \mathrm{He} \\
\text { reactions. } \\
\text { Activation energy for parabolic } \\
\text { reaction with oxygen addition: } \\
27.5 \mathrm{kcal} / \mathrm{mol} \text {. }\end{array}$ & $\begin{array}{l}\mathrm{UO}_{2+x} \\
\mathrm{UH}_{3-y}\end{array}$ \\
\hline $\begin{array}{l}\text { Bennett et al. } \\
\text { (1975) }\end{array}$ & $\begin{array}{l}\text { U; } \\
\text { Al: } 780 \mathrm{ppm} \\
\text { Fe: } 150 \mathrm{ppm} \\
\text { Ni: } 20 \mathrm{ppm} \\
\text { C: } 1100 \mathrm{ppm}\end{array}$ & $\begin{array}{l}\text { Moist air: } \\
10-20 \text { vpm and } \\
2-3 \times 10^{4} \text { vpm } \mathrm{H}_{2} \mathrm{O}\end{array}$ & $60-120^{\circ} \mathrm{C}$ & Linear & $\begin{array}{l}10-20 \mathrm{vpm} \mathrm{H}_{2} \mathrm{O}: \\
k=8.24 \times 10^{6} \exp (-8240 / T(\mathrm{~K})) \\
\mathrm{mg} / \mathrm{cm}^{2} \cdot \mathrm{hr} \\
2-3 \times 10^{4} \mathrm{vpm} \mathrm{H}_{2} \mathrm{O}_{i} \\
k=5.34 \times 10^{6} \exp (-7510 / T(\mathrm{~K})) \\
\mathrm{mg} / \mathrm{cm}^{2} \cdot \mathrm{hr}\end{array}$ & $\begin{array}{l}\mathrm{UO}_{2+\mathrm{x}} ; \\
\text { adsorbed } \mathrm{H}_{2} \mathrm{O} \text {. }\end{array}$ \\
\hline $\begin{array}{l}\text { Bennett and Price } \\
\text { (1981) }\end{array}$ & $\begin{array}{l}\text { U; } \\
\text { Al: } 1200 p p m \\
\text { Fe: } 310 \text { ppm }\end{array}$ & $\begin{array}{l}\text { Moist air: } \\
2.5 \times 10^{4} \text { vpm } \mathrm{H}_{2} \mathrm{O}\end{array}$ & $50-450^{\circ} \mathrm{C}$ & Linear & $\begin{array}{l}k=4.08 \times 10^{6} \exp (-7792 / T(K)) \\
\mathrm{mg} / \mathrm{cm}^{2} \cdot \mathrm{hr}\end{array}$ & $\begin{array}{l}\text { Not specifically } \\
\text { mentioned. }\end{array}$ \\
\hline $\begin{array}{l}\text { Ritchie } \\
(1981,1984)\end{array}$ & $\mathbf{U}$ & $\begin{array}{l}\mathrm{H}_{2} \mathrm{O}: \\
\text { varying pressure } \\
\mathrm{H}_{2} \mathrm{O}-\mathrm{O}_{2} \\
2-90 \% \mathrm{RH} \\
100 \% \mathrm{RH}\end{array}$ & $20-100^{\circ} \mathrm{C}$ & Linear & $\begin{array}{l}\text { Best fit to available literature: } \\
\mathrm{H}_{2} \mathrm{O} \text { : } \\
k=1.3 \times 10^{4} P_{\mathrm{H} 2 \mathrm{O}} \exp (-4500 / T(\mathrm{~K})) \\
\mathrm{mg} / \mathrm{cm}^{2} \cdot \mathrm{hr} \\
\underline{\mathrm{H}}_{2} \mathrm{O}-\mathrm{O}_{2}(2-90 \% \mathrm{RH}): \\
k=4.8 \times 10^{13} \exp (-12500 / T(\mathrm{~K})) \\
\mathrm{mg} / \mathrm{cm}^{2} \cdot \mathrm{hr} \\
\mathrm{H}_{2} \mathrm{O}-\mathrm{O}_{2}(100 \% \mathrm{RH}): \\
k=4.6 \times 10^{9} \exp (-8900 / T(\mathrm{~K})) \\
\mathrm{mg} / \mathrm{cm}^{2} \cdot \mathrm{hr}\end{array}$ & \\
\hline
\end{tabular}


TABLE II. Summary Table for Uranium Reaction with Water Vapor (Contd)

\begin{tabular}{|c|c|c|c|c|c|c|}
\hline Reference & $\begin{array}{l}\text { Metal Type; } \\
\text { Impurities }\end{array}$ & Environment & $\begin{array}{c}\text { Temperature } \\
\text { Range } \\
\end{array}$ & $\begin{array}{l}\text { Kinetic } \\
\text { Behavior } \\
\end{array}$ & $\begin{array}{c}\text { Rate } \\
\text { Equations }\end{array}$ & \begin{tabular}{|l|} 
Reaction \\
Products \\
\end{tabular} \\
\hline $\begin{array}{l}\text { Colmenares et al. } \\
\text { (1981) }\end{array}$ & $\begin{array}{l}\mathrm{U} ; \\
\mathrm{C}: 19 \mathrm{ppm} \\
\mathrm{N}: 17 \mathrm{ppm} \\
\text { O: } 18 \mathrm{ppm} \\
\text { (97 } \mathrm{ppm} \text { total) }\end{array}$ & $\begin{array}{l}\mathrm{H}_{2} \mathrm{O}-\mathrm{N}_{2}: \\
0.05-106 \text { Torr } \\
\mathrm{H}_{2} \mathrm{O} \\
\\
\mathrm{H}_{2} \mathrm{O}-\mathrm{O}_{2}: \\
98 \text { Torr } \mathrm{H}_{2} \mathrm{O} \text {, } \\
7.6 \times 10^{-4}=479 \\
\text { Torr } \mathrm{O}_{2} \\
\\
\text { Humid air: } \\
\text { 2.25-127 Torr } \\
\mathrm{H}_{2} \mathrm{O}\end{array}$ & $62-100^{\circ} \mathrm{C}$ & $\begin{array}{l}\mathrm{H}_{2} \mathrm{O}-\mathrm{N}_{2}: \\
\text { Linear } \\
\mathrm{H}_{2} \mathrm{O}-\mathrm{O}_{2} \text { : } \\
\text { Linear } \\
\text { Humid air: } \\
\text { I. linear } \\
\text { II. accelerating } \\
\text { III. final linear }\end{array}$ & 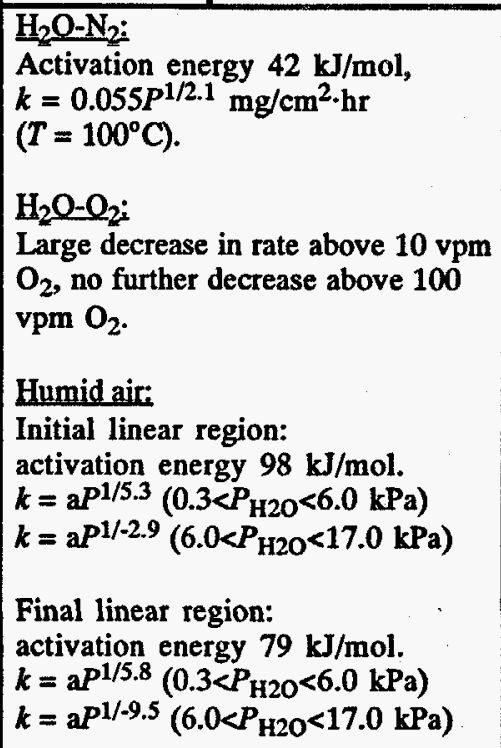 & $\begin{array}{l}\mathrm{H}_{2} \mathrm{O}-\mathrm{N}_{2}: \\
\mathrm{UO}_{2.0} \\
\\
\text { Humid air } \\
\left(2.3 \text { Torr } \mathrm{H}_{2} \mathrm{O}\right) \text { : } \\
\mathrm{U}_{4} \mathrm{O}_{9-\mathrm{y}} \\
\\
\mathrm{Humid} \text { air } \\
\left(1_{00} \text { Torr } \mathrm{H}_{2} \mathrm{O}\right) \text { : } \\
\mathrm{UO}_{2.20}\end{array}$ \\
\hline $\begin{array}{l}\text { Weirick } \\
\text { (1984) }\end{array}$ & $\begin{array}{l}\mathrm{U} ; \\
\mathrm{C}: 19 \mathrm{ppm} \\
\mathrm{N}: 17 \mathrm{ppm} \\
\mathrm{O}: 18 \mathrm{ppm} \\
\text { (100 ppm total) }\end{array}$ & $\begin{array}{l}\mathrm{H}_{2} \mathrm{O}: \\
2-20 \text { Torr } \\
\\
\mathrm{H}_{2} \mathrm{O}-\mathrm{O}_{2}: \\
\text { varying } \mathrm{O}_{2} \text { and } \\
\mathrm{H}_{2} \mathrm{O} \text { pressure. }\end{array}$ & $100^{\circ} \mathrm{C}$ & $\begin{array}{l}\mathrm{H}_{2} \mathrm{O}: \\
\text { linear } \\
\\
\mathrm{H}_{2} \mathrm{O}-\mathrm{O}_{2}: \\
\text { linear }\end{array}$ & $\begin{array}{l}\underline{\mathrm{H}}_{2} \mathrm{O}: \\
k=6.25 \times 10^{-2} \mathrm{mg} / \mathrm{cm}^{2} \cdot \mathrm{hr} \\
(P=15 \mathrm{Torr}) \\
k \propto P^{1 / 2.1} \\
\mathrm{H}_{2} \mathrm{O} \cdot \mathrm{O}_{2} \mathrm{i} \\
P_{\mathrm{O} 2}<0.05 \text { Torr: } \\
\text { same as } \mathrm{H}_{2} \mathrm{O} \text { rnn. } \\
0.05<P_{\mathrm{O} 2}<1 \text { Torr: } \\
\text { dependent on } P_{\mathrm{H} 2 \mathrm{O}} \\
P_{\mathrm{O} 2}>1 \mathrm{Torr} \\
k=1.2 \times 10^{-2} \mathrm{mg} / \mathrm{cm}^{2} \cdot \mathrm{hr} \\
\text { rate indep. of } P_{\mathrm{O} 2} \text { and } P_{\mathrm{H} 2 \mathrm{O}}\end{array}$ & $\begin{array}{l}\mathrm{H}_{2} \mathrm{O}: \\
\mathrm{UO}_{2.0} \\
\\
\mathrm{H}_{2} \mathrm{O}-\mathrm{O}_{2}: \\
P_{\mathrm{O}_{2}}<0.05 \text { Torr: } \\
\mathrm{UO}_{2.0} \\
0.05<\mathrm{P}_{\mathrm{O} 2}<1 \text { Torr: } \\
\mathrm{UO}_{2.0} \\
\mathrm{P}_{\mathrm{O}_{2}}>1 \text { Torr: } \\
\mathrm{UO}_{2.25}\end{array}$ \\
\hline
\end{tabular}


TABLE II. Summary Table for Uranium Reaction with Water Vapor (Contd)

\begin{tabular}{|c|c|c|c|c|c|c|}
\hline $\begin{array}{l}\text { Ritchie et al. } \\
\text { (1986) }\end{array}$ & $\begin{array}{l}\mathrm{U} ; \\
\mathrm{C}, \mathrm{Fe}<80 \mathrm{ppm} \\
\mathrm{Si}<60 \mathrm{ppm} \\
\mathrm{Ni}<30 \mathrm{ppm} \\
\mathrm{Mo}<200 \mathrm{ppm}\end{array}$ & $\begin{array}{l}\text { Moist air: } \\
\text { 11-75\% R.H. }\end{array}$ & $40-100^{\circ} \mathrm{C}$ & Linear & $\begin{array}{l}k=7.6 \times 10^{13} \exp (-13260 / T(\mathrm{~K})) \\
\mathrm{mg} / \mathrm{cm}^{2} \cdot \mathrm{hr} \\
\text { No variation in rate with humidity. }\end{array}$ & $\begin{array}{l}\text { Not specifically } \\
\text { mentioned. }\end{array}$ \\
\hline $\begin{array}{l}\text { McGillivray et al. } \\
\text { (1994) }\end{array}$ & $\begin{array}{l}\mathrm{U} ; \\
\mathrm{Fe}, \mathrm{C}, \mathrm{Ni}, \mathrm{Al} \\
\text { (< } 100 \mathrm{ppm} \text { total) }\end{array}$ & $\begin{array}{l}\text { Moist air: } \\
\text { 0-353 Torr } \mathrm{H}_{2} \mathrm{O}\end{array}$ & $115-350^{\circ} \mathrm{C}$ & $\begin{array}{l}\text { Initially } \\
\text { parabolic, then } \\
\text { linear. }\end{array}$ & $\begin{array}{l}k=\frac{k_{1} P_{\text {tot }}}{1+k_{2} P_{\text {tot }}}+D \\
\text { with } \\
D=3.94 \times 10^{6} \exp (-8077 / T(\mathrm{~K})) \\
k_{1}=1.51 \times 10^{5} \exp (-6432 / T(\mathrm{~K})) \\
k_{2}=2.02 \times 10^{8} \exp (-5327 / T(\mathrm{~K})) \\
\mathrm{mg} / \mathrm{cm}^{2} \cdot \mathrm{hr}\end{array}$ & $\mathrm{UO}_{2}$ \\
\hline
\end{tabular}


TABLE III. General Factors Influencing the Rates of Generation and Loss of Heat in Ignition (adapted from Schnizlein et al., 1959)

\begin{tabular}{lll}
\hline \multicolumn{1}{c}{ Step } & Possible Factors Influencing Rate \\
\hline Metal surface of unit area & (1) Metal purity \\
oxidizing in air: & (2) Metallurgical condition \\
& (grain size, strains, etc.) \\
& (4) Temperature \\
& (5) Gas Composition \\
Loss of heat of reaction by & (1) Thermal conductivity of metal \\
conduction to the & (2) Thermal conductivity of oxide coating \\
surroundings. & (3) Cross-sectional area at right angles to \\
& (4) Temperature gradient \\
\hline
\end{tabular}


TABLE IV. Summary Table for Plutonium Reaction with Dry Air/ $\mathrm{O}_{2}$

\begin{tabular}{|c|c|c|c|c|c|c|}
\hline Reference & $\begin{array}{l}\text { Metal Type; } \\
\text { Impurities }\end{array}$ & Environment & $\begin{array}{c}\text { Temperature } \\
\text { Range }\end{array}$ & $\begin{array}{l}\text { Kinetic } \\
\text { Behavior }\end{array}$ & $\begin{array}{c}\text { Rate } \\
\text { Equations }\end{array}$ & $\begin{array}{l}\text { Reaction } \\
\text { Products }\end{array}$ \\
\hline $\begin{array}{l}\text { Thompson } \\
\text { (1965) }\end{array}$ & $\begin{array}{l}\text { Pu; } \\
\text { Impurities not } \\
\text { reported. }\end{array}$ & $\begin{array}{l}\mathrm{O}_{2}: \\
620 \text { Torr }\end{array}$ & $25-320^{\circ} \mathrm{C}$ & Linear & $\begin{array}{l}\text { Rates dependent on metal phase: } \\
\alpha: \\
k \propto \exp (-11560 / T(\mathrm{~K})) \\
\underline{B}: \\
k \propto \exp (-6030 / T(\mathrm{~K})) \\
\psi \\
k \propto \exp (-7030 / T(\mathrm{~K}))\end{array}$ & Not reported. \\
\hline $\begin{array}{l}\text { Tanon and } \\
\text { Bordes-Pages } \\
(1965)\end{array}$ & $\begin{array}{l}\text { Pu; } \\
\text { U: } 500 \mathrm{ppm} \\
\mathrm{Ni}: 200 \mathrm{ppm} \\
\mathrm{Mg}: 150 \mathrm{ppm} \\
\text { Fe: } 100 \mathrm{ppm} \\
\text { Zn: } 100 \mathrm{ppm} \\
\text { Ca: } 100 \mathrm{ppm}\end{array}$ & $\overline{\mathrm{O}_{2}}$ & $\begin{array}{l}50^{\circ} \mathrm{C} \\
70^{\circ} \mathrm{C}\end{array}$ & Linear & $\begin{array}{l}\text { Not measurable at } 50^{\circ} \mathrm{C} \text {. } \\
70^{\circ} \mathrm{C}: \\
k=0.0128 \mathrm{mg} / \mathrm{cm}^{2} \cdot \mathrm{hr}\end{array}$ & Not reported. \\
\hline $\begin{array}{l}\text { Schnizlein and } \\
\text { Fischer (1967) }\end{array}$ & $\begin{array}{l}\text { Pu; } \\
\text { Fe: } 30 \mathrm{ppm} \\
\text { Am: } 38 \mathrm{ppm} \\
\text { U: } 22 \mathrm{ppm} \\
\text { C: } 19 \mathrm{ppm} \\
\text { Ni: } 18 \mathrm{ppm}\end{array}$ & $\overline{\mathrm{O}_{2}}$ & $140-400^{\circ} \mathrm{C}$ & $\begin{array}{l}\text { Initially } \\
\text { parabolic, then } \\
\text { linear. }\end{array}$ & $\begin{array}{l}\text { Parabolic: } \\
k=3.30 \times 10^{12} \exp (-14670 / T(\mathrm{~K})) \\
\left(\mathrm{mg} / \mathrm{cm}^{2}\right)^{2} / \mathrm{hr} \\
\text { Linear: } \\
k=9.60 \times 10^{6} \exp (-8440 / T(\mathrm{~K})) \\
\mathrm{mg} / \mathrm{cm}^{2} \cdot \mathrm{hr}\end{array}$ & $\mathrm{Pu}_{2} \mathrm{O}_{3}$ \\
\hline $\begin{array}{l}\text { Sakebake } \\
(1986)\end{array}$ & $\begin{array}{l}\text { Pu-1w/oGa; } \\
\text { Al: } 22 \mathrm{ppm} \\
\text { Cr: } 24 \mathrm{ppm} \\
\text { Fe: } 61 \mathrm{ppm} \\
\text { Ni: } 30 \mathrm{ppm} \\
\text { Np: } 22 \mathrm{ppm} \\
\text { U: } 260 \mathrm{ppm}\end{array}$ & $\begin{array}{l}\text { Dry air: } \\
500 \text { Torr }\end{array}$ & $150-300^{\circ} \mathrm{C}$ & $\begin{array}{l}\text { Initially } \\
\text { parabolic, then } \\
\text { two linear stages. }\end{array}$ & $\begin{array}{l}\text { Parabolic: } \\
k^{2}=1.86 \times 10^{7} \exp (-11060 / T(\mathrm{~K})) \\
\mathrm{mg} / \mathrm{cm}^{2} \cdot \mathrm{hr}^{1 / 2} \\
\text { Linear } 1: \\
k=5.88 \times 10^{6} \exp (-9550 / T(\mathrm{~K})) \\
\text { Linear 2: } \\
k=4.08 \times 10^{6} \exp (-27140 / T(\mathrm{~K})) \\
\mathrm{mg} / \mathrm{cm}^{2} \cdot \mathrm{hr}\end{array}$ & $\mathrm{PuO}_{2}$ \\
\hline $\begin{array}{l}\text { Stakebake and } \\
\text { Lewis (1987) }\end{array}$ & $\begin{array}{l}\text { Pu-1w/oGa; } \\
\text { Al: } 22 \mathrm{ppm} \\
\text { Cr: } 24 \mathrm{ppm} \\
\text { Fe: } 61 \mathrm{ppm} \\
\text { Ni: } 30 \mathrm{ppm} \\
\text { Np: } 22 \mathrm{ppm} \\
\text { U: } 260 \mathrm{ppm}\end{array}$ & $\begin{array}{l}\mathrm{N}_{2}-5.5 \% \mathrm{O}_{2} \\
500 \text { Torr }\end{array}$ & $150-300^{\circ} \mathrm{C}$ & $\begin{array}{l}\text { Initially } \\
\text { parabolic, then } \\
\text { two linear stages. }\end{array}$ & $\begin{array}{l}\text { Parabolic: } \\
k^{2}=3.02 \times 10^{8} \exp (-12560 / T(\mathrm{~K})) \\
\mathrm{mg} / \mathrm{cm}^{2} \cdot \mathrm{hr}^{1 / 2} \\
\text { Linear } 1: \\
k=3.12 \times 10^{7} \exp (-10550 / T(\mathrm{~K})) \\
\text { Linear } 2: \\
k=1.08 \times 10^{6} \exp (-8540 / T(\mathrm{~K})) \\
\mathrm{mg} / \mathrm{cm}^{2} \cdot \mathrm{hr}\end{array}$ & Not reported. \\
\hline
\end{tabular}


TABLE V. Summary Table for Plutonium Reaction with Water Vapor

\begin{tabular}{|c|c|c|c|c|c|c|}
\hline Reference & $\begin{array}{l}\text { Metal Type; } \\
\text { Impurities }\end{array}$ & Environment & $\begin{array}{c}\text { Temperature } \\
\text { Range }\end{array}$ & $\begin{array}{l}\text { Kinetic } \\
\text { Behavior }\end{array}$ & $\begin{array}{c}\text { Rate } \\
\text { Equations }\end{array}$ & $\begin{array}{l}\text { Reaction } \\
\text { Products }\end{array}$ \\
\hline $\begin{array}{l}\text { Raynor and } \\
\text { Sackman (1963) }\end{array}$ & $\begin{array}{l}\text { Pu; } \\
\text { Impurities not } \\
\text { reported. }\end{array}$ & $\begin{array}{l}\text { Moist air } \\
\text { Moist Ar }\end{array}$ & $25^{\circ} \mathrm{C}$ & Linear & $\begin{array}{l}\text { Air: } \\
k \text { from } 2.8 \times 10^{-4} \text { to } 9.6 \times 10^{-4} \\
\mathrm{mg} / \mathrm{cm}^{2} \cdot \mathrm{hr} \\
\mathrm{Ar} \\
k \text { from } 4.0 \times 10^{-4} \text { to } 8.7 \times 10^{-4} \\
\mathrm{mg} / \mathrm{cm}^{2} \cdot \mathrm{hr}\end{array}$ & Not reported. \\
\hline $\begin{array}{l}\text { Thompson } \\
\text { (1966) }\end{array}$ & $\begin{array}{l}\text { Pu; } \\
\text { Impurities not } \\
\text { reported. }\end{array}$ & $\begin{array}{l}\mathrm{H}_{2} \mathrm{O} \text { (vapor): } \\
24 \text { Torr }\end{array}$ & $100-200^{\circ} \mathrm{C}$ & $\begin{array}{l}\text { Approximately } \\
\text { parabolic. }\end{array}$ & None reported. & $\begin{array}{l}\mathrm{PuO}_{2-x} \\
\mathrm{PuH}_{2-x}\end{array}$ \\
\hline $\begin{array}{l}\text { Raynor and } \\
\text { Sackman (1967) }\end{array}$ & $\begin{array}{l}\text { Pu; } \\
\text { Impurities not } \\
\text { reported. }\end{array}$ & $\begin{array}{l}\text { Moist air: } \\
\text { varying } \\
\text { humidities }\end{array}$ & $90^{\circ} \mathrm{C}$ & Linear & $\begin{array}{l}\text { Sigmoidal relationship of rates } \\
\text { with humidity (see Figure } 8 \text { ). }\end{array}$ & $\begin{array}{l}\mathrm{PuO}_{2} \\
\mathrm{PuO}_{2} \cdot \mathrm{xH}_{2} \mathrm{O} \\
x=0.07\end{array}$ \\
\hline $\begin{array}{l}\text { Schnizlein and } \\
\text { Fischer (1967) }\end{array}$ & $\begin{array}{l}\text { Pu; } 30 \mathrm{ppm} \\
\text { Fe: } 30 \mathrm{pm} \\
\text { Am: } 38 \mathrm{ppm} \\
\text { U: } 22 \mathrm{ppm} \\
\text { C: } 19 \mathrm{ppm} \\
\text { Ni: } 18 \mathrm{ppm}\end{array}$ & $\begin{array}{l}\text { Moist air up to } \\
510 \text { ppm } \mathrm{H}_{2} \mathrm{O} \text {. }\end{array}$ & $140-190^{\circ} \mathrm{C}$ & Linear & $\begin{array}{l}140^{\circ} \mathrm{C}: \\
k=0.72-1.5 \mathrm{mg} / \mathrm{cm}^{2} \cdot \mathrm{hr} \\
190^{\circ} \mathrm{C}: \\
k=0.96-1.8 \mathrm{mg} / \mathrm{cm}^{2} \cdot \mathrm{hr} \\
\text { Approximately order of magnitude } \\
\text { increase over dry air rates. }\end{array}$ & Not reported. \\
\hline $\begin{array}{l}\text { Stakebake and } \\
\text { Steward (1972) }\end{array}$ & $\begin{array}{l}\text { Pu; } \\
\text { Rolled: } \\
3010 \text { ppm total } \\
\text { Cast: } \\
435 \text { ppm total }\end{array}$ & $\begin{array}{l}\text { Moist } \mathrm{O}_{2}-\mathrm{N}_{2} \\
\text { Moist } \mathrm{N}_{2} \\
500 \text { Torr } P_{\text {tot, }} \\
5 \text { and } 12,000 \text { ppm } \\
\mathrm{H}_{2} \mathrm{O}\end{array}$ & $90^{\circ} \mathrm{C}$ & $\begin{array}{l}\text { Moist } \mathrm{O}_{2}-\mathrm{N}_{2}: \\
\text { linear. } \\
\text { Moist } \mathrm{N}_{2} \text { : } \\
\text { parabolic. }\end{array}$ & $\begin{array}{l}\text { Moist } \mathrm{O}_{2}-\mathrm{N}_{2} \\
\text { Cast: } \\
k=0.68 \mathrm{mg} / \mathrm{cm}^{2} \cdot \mathrm{hr} \\
\text { Rolled: } \\
k=0.34 \mathrm{mg} / \mathrm{cm}^{2} \cdot \mathrm{hr} \\
\text { Moist } \mathrm{N}_{2} \\
\text { Cast: } \\
k_{\mathrm{p}}=3.60 \mathrm{mg} / \mathrm{cm}^{2} \cdot \mathrm{hr}^{1 / 2} \\
\text { Rolled: } \\
k_{\mathrm{p}}=1.11 \mathrm{mg} / \mathrm{cm}^{2} \cdot \mathrm{hr}^{1 / 2}\end{array}$ & $\begin{array}{l}\mathrm{PuO}_{2} \\
\mathrm{No} \mathrm{PuH}_{2}\end{array}$ \\
\hline
\end{tabular}


TABLE V. Summary Table for Plutonium Reaction with Water Vapor (Contd)

\begin{tabular}{|c|c|c|c|c|c|c|}
\hline Reference & $\begin{array}{l}\text { Metal Type; } \\
\text { Impurities }\end{array}$ & Environment & $\begin{array}{c}\text { Temperature } \\
\text { Range }\end{array}$ & $\begin{array}{c}\text { Kinetic } \\
\text { Behavior }\end{array}$ & $\begin{array}{c}\text { Rate } \\
\text { Equations }\end{array}$ & $\begin{array}{l}\text { Reaction } \\
\text { Products } \\
\end{array}$ \\
\hline $\begin{array}{l}\text { Stakebake and } \\
\text { Saba (1990) }\end{array}$ & $\begin{array}{l}\text { Pu-1w/oGa; } \\
\text { Am: } 2460 \mathrm{ppm} \\
\text { Fe: } 239 \mathrm{ppm} \\
\mathrm{Ni}: 112 \mathrm{ppm} \\
\text { Si: } 61 \mathrm{ppm} \\
\mathrm{Cr}: 54 \mathrm{ppm} \\
\text { Al: } 41 \mathrm{ppm} \\
\mathrm{Pb}: 31 \mathrm{ppm} \\
\mathrm{Zr}: 25 \mathrm{ppm}\end{array}$ & $\begin{array}{l}\mathrm{H}_{2} \mathrm{O} \text { (vapor): } \\
0.1-15 \text { Torr }\end{array}$ & $100-540^{\circ} \mathrm{C}$ & $\begin{array}{l}\text { Three stages: } \\
\text { I. parabolic } \\
\text { II. linear } \\
\text { III. linear }\end{array}$ & $\begin{array}{l}\text { Stage I: } \\
\text { Activation energy } 15.1 \mathrm{kcal} / \mathrm{mol} \text {. } \\
\text { Indep. of } P \text { for } P<1.5 \text { Torr, } \\
k_{\mathrm{p}}=4.62 P^{0.15} \mathrm{mg} / \mathrm{cm}^{2} \cdot \mathrm{hr}^{1 / 2} \\
\text { for } P>1.5 \text { Torr }\left(T=300^{\circ} \mathrm{C}\right) \\
\text { Stage III: } \\
\text { Activation energy } 15.6 \mathrm{kcal} / \mathrm{mol} \text {. } \\
k=0.24 P^{0.23} \mathrm{mg} / \mathrm{cm}^{2} \cdot \mathrm{hr} \\
\left(T=300^{\circ} \mathrm{C}\right) \text {. } \\
\text { Stage III: } \\
\text { Activation energy } 2.7 \mathrm{kcal} / \mathrm{mol} \text {. } \\
k=3.36 P^{0.99} \mathrm{mg} / \mathrm{cm}^{2} \cdot \mathrm{hr} \\
\left(T=300^{\circ} \mathrm{C}\right) .\end{array}$ & $\begin{array}{l}\mathrm{PuO}_{2} \\
\mathrm{Pu}_{2} \mathrm{O}_{3} \\
\mathrm{PuH}_{2} \\
\mathrm{PuO}_{3} \\
\\
\text { (Data from } \\
\text { Stakebake et al. } \\
(1993) . \text { ) }\end{array}$ \\
\hline $\begin{array}{l}\text { Stakebake } \\
\text { (1992) }\end{array}$ & $\begin{array}{l}\mathrm{Pu} ; \\
102 \mathrm{ppm} \text { total }\end{array}$ & $\begin{array}{l}\mathrm{H}_{2} \mathrm{O} \text { (vapor): } \\
15 \text { Torr }\end{array}$ & $200-350^{\circ} \mathrm{C}$ & $\begin{array}{l}\text { Parabolic } \\
\text { changing to } \\
\text { linear. }\end{array}$ & $\begin{array}{l}\text { Linear: } \\
\text { Activation energy } 13 \mathrm{kcal} / \mathrm{mol} \text {. }\end{array}$ & $\begin{array}{l}\mathrm{PuO}_{2} \\
\mathrm{Pu}_{2} \mathrm{O}_{3} \\
\mathrm{PuH}_{2}\end{array}$ \\
\hline
\end{tabular}




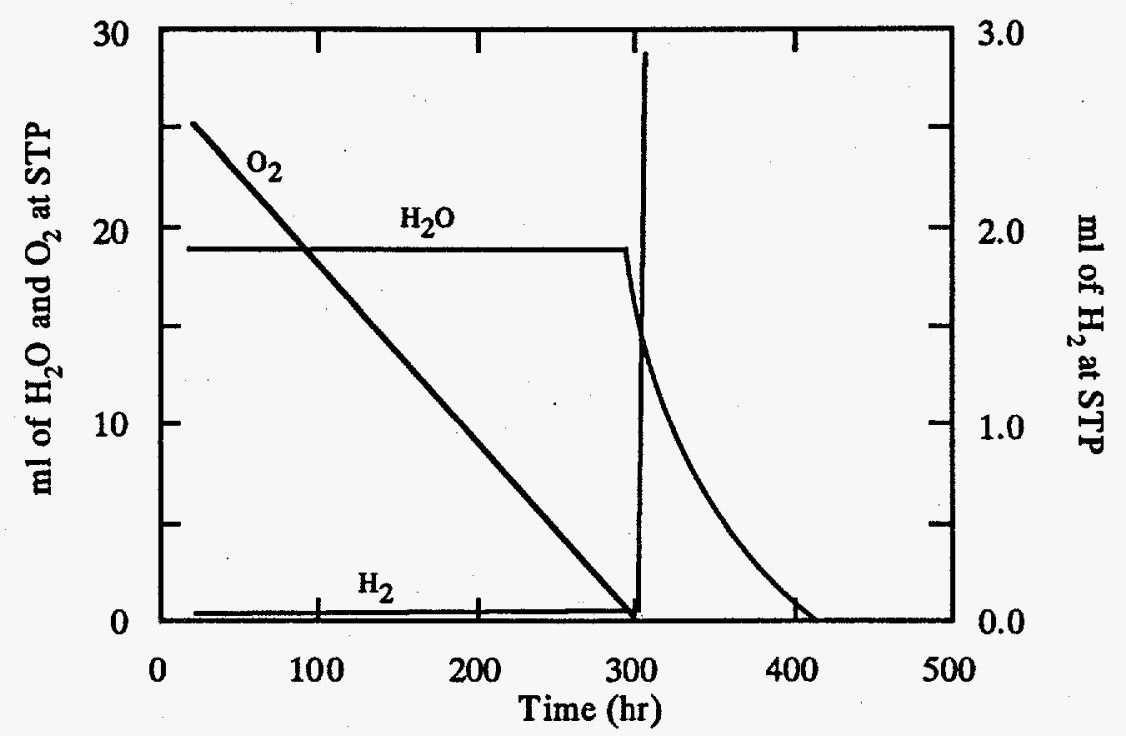

Fig. 1. Variations of hydrogen, oxygen, and water vapor gas concentrations with time during the reaction of uranium with a water vapor - oxygen mixture (adapted from Baker et al., 1966b).

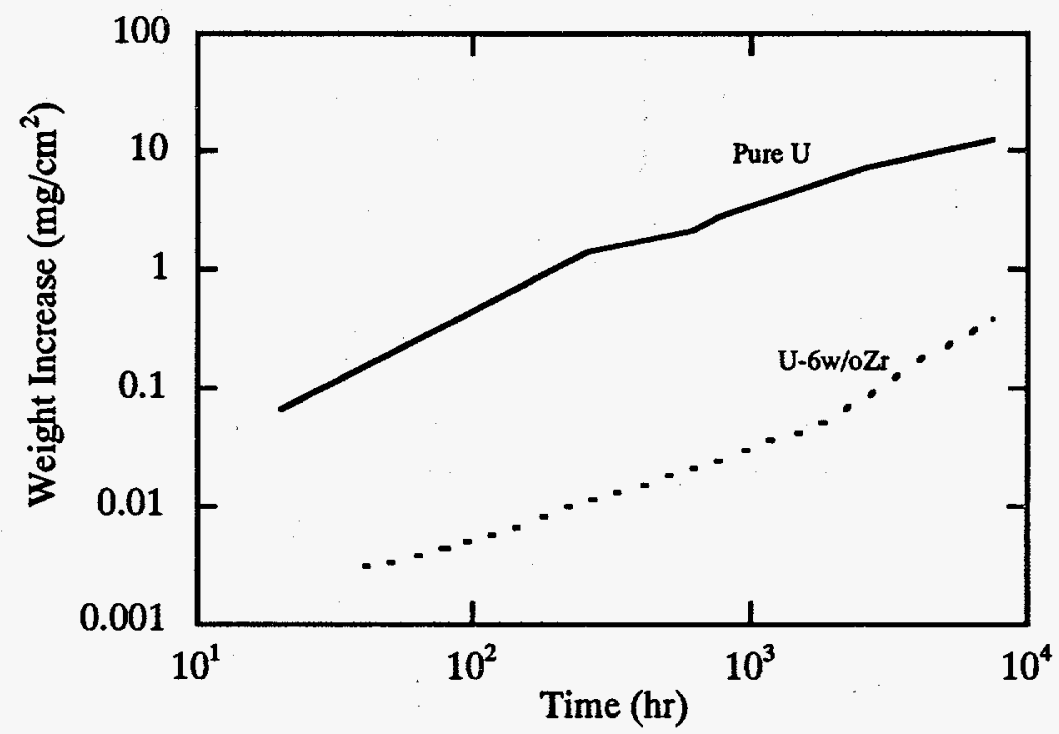

Fig. 2. Oxidation rates of uranium and a U-6w/oZr alloy (quenched from $850^{\circ} \mathrm{C}$ ) at $75^{\circ} \mathrm{C}$ in air containing $50 \%$ relative humidity (adapted from Waber, 1958). 


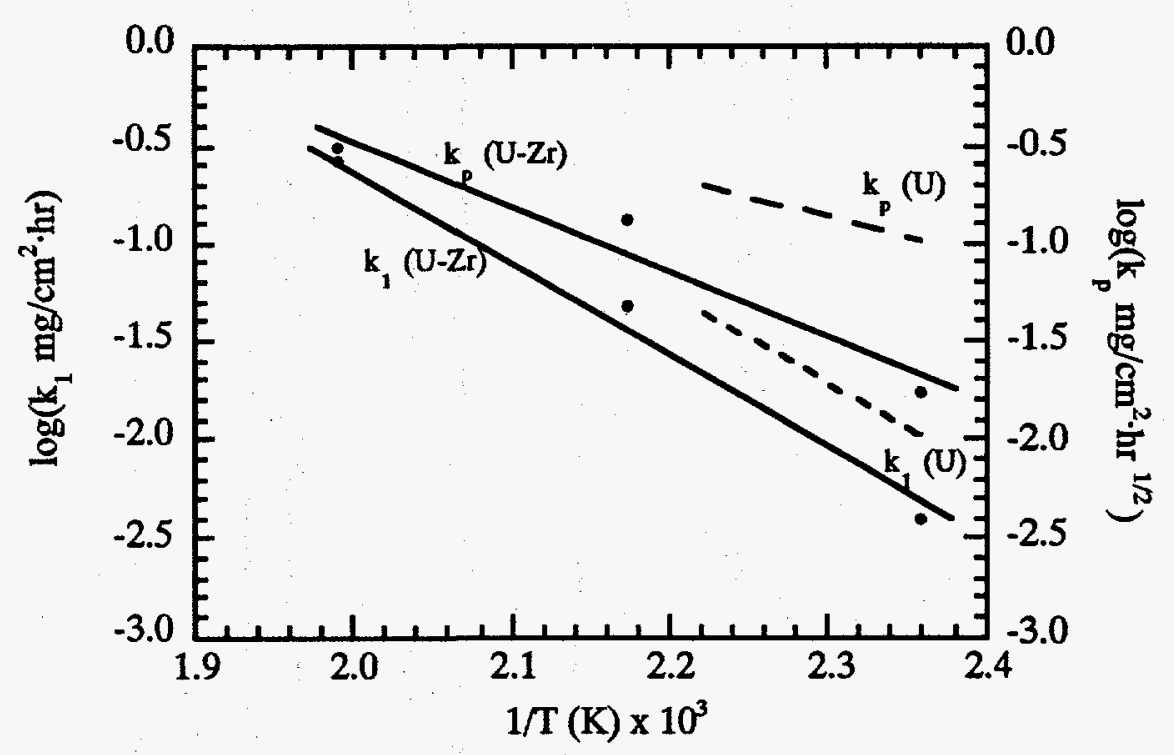

Fig. 3. Variation of paralinear oxidation rate constants for uranium and a U-20w/oZr alloy in gaseous oxygen (adapted from Matsui et al., 1993).

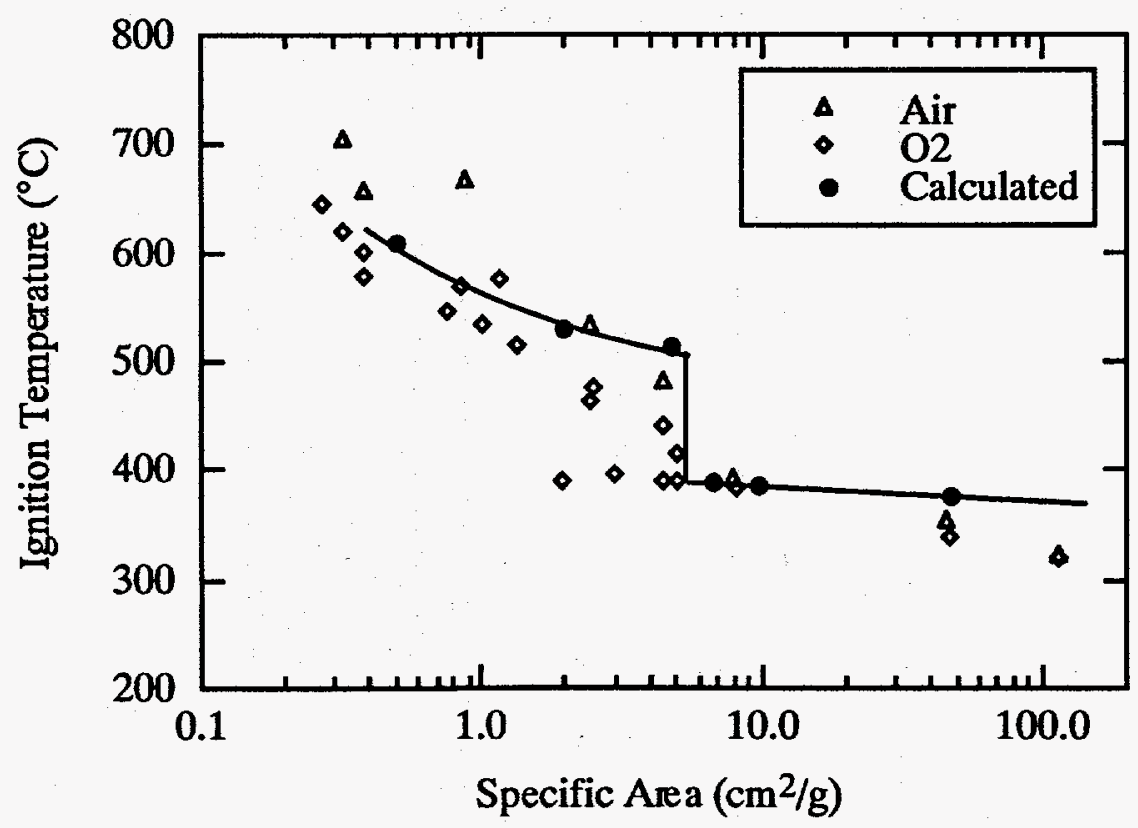

Fig. 4. Uranium ignition temperatures for solid specimens as a function of specific area (adapted from Baker, Schnizlein, and Ringle, 1966). 


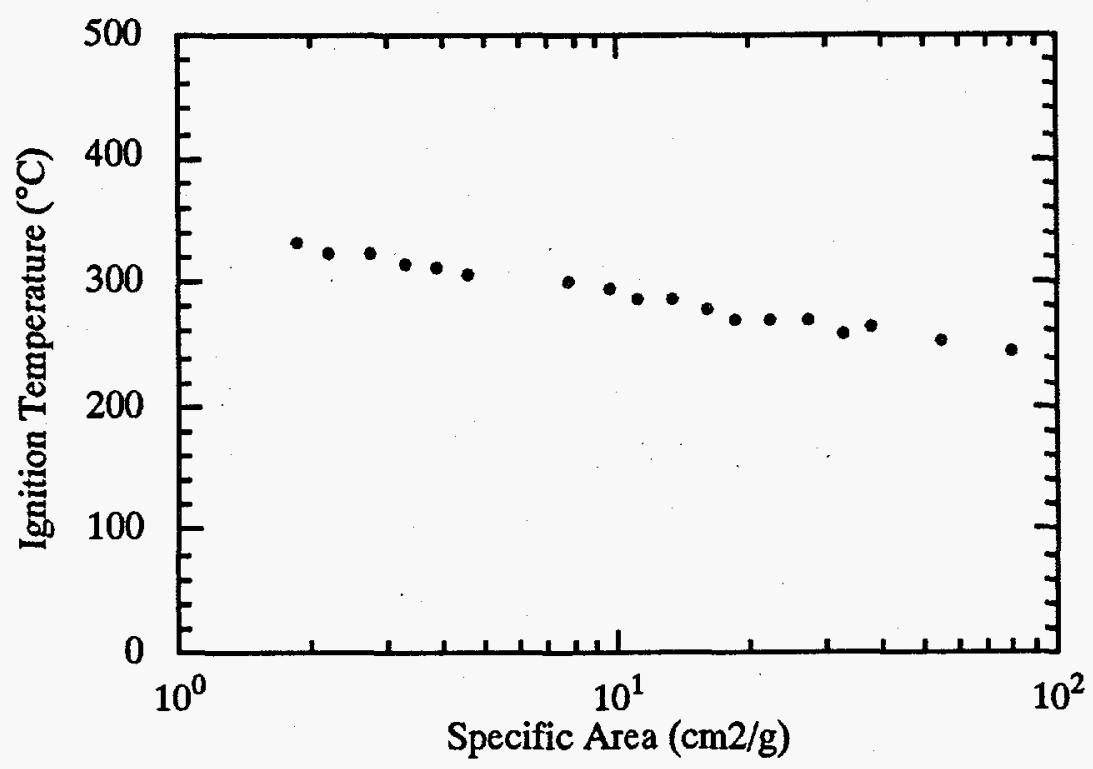

Fig. 5. Ignition temperatures of uranium powders in oxygen as a function of specific area (adapted from Tetenbaum et al., 1962).

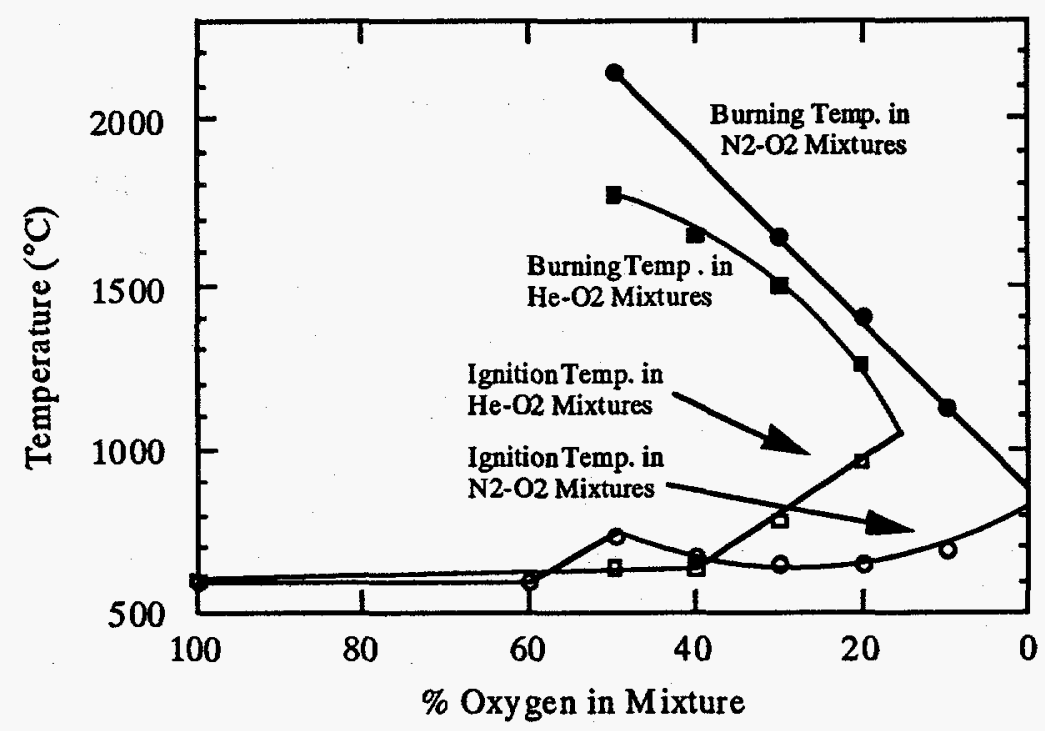

Fig. 6. The effect of oxygen concentration on ignition and burning temperatures of $8.5 \mathrm{~mm}$ uranium cubes (adapted from Schnizlein et al., 1959). 


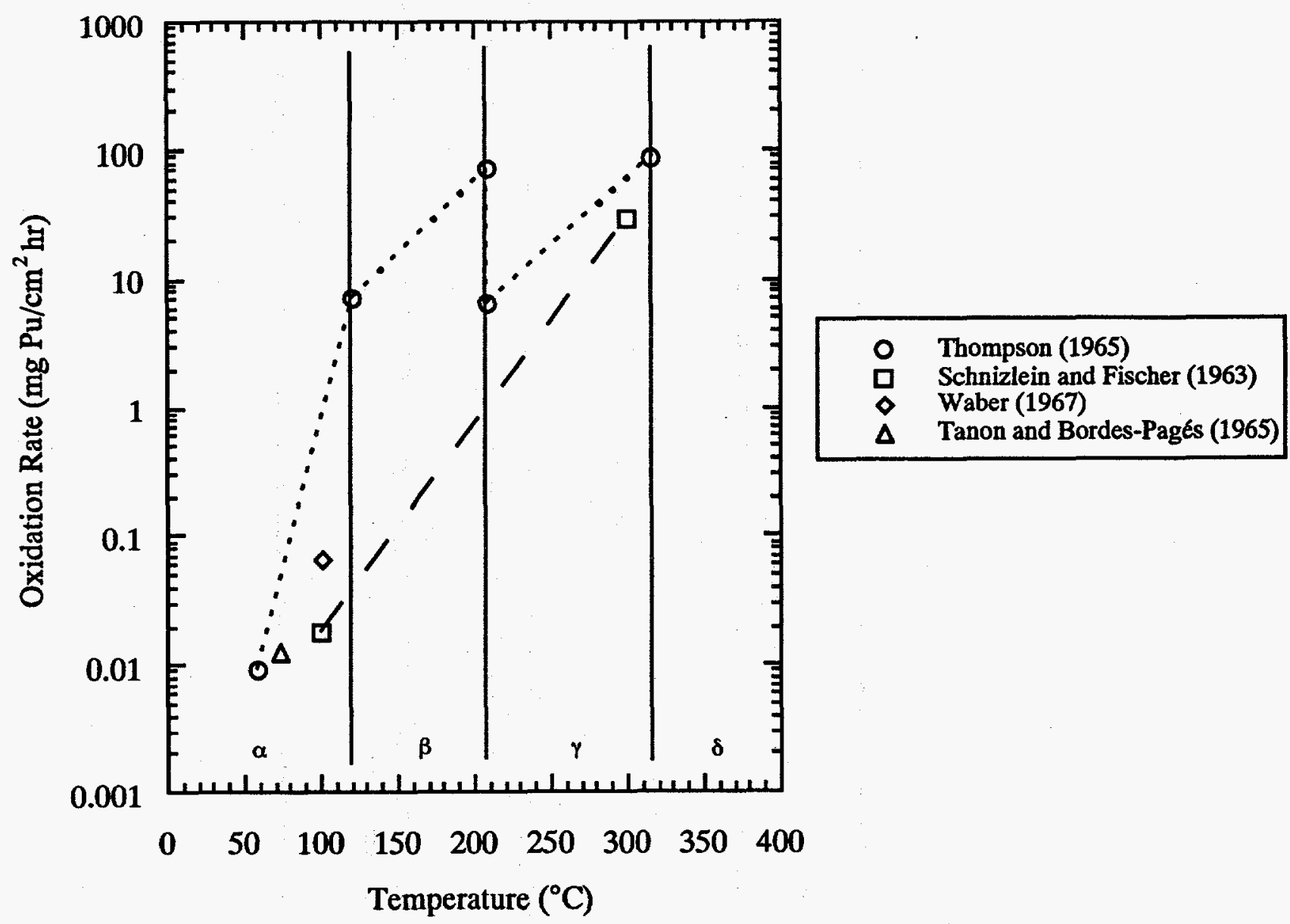

Fig. 7. Oxidation rates observed for plutonium in oxygen and dry air as a function of temperature. 


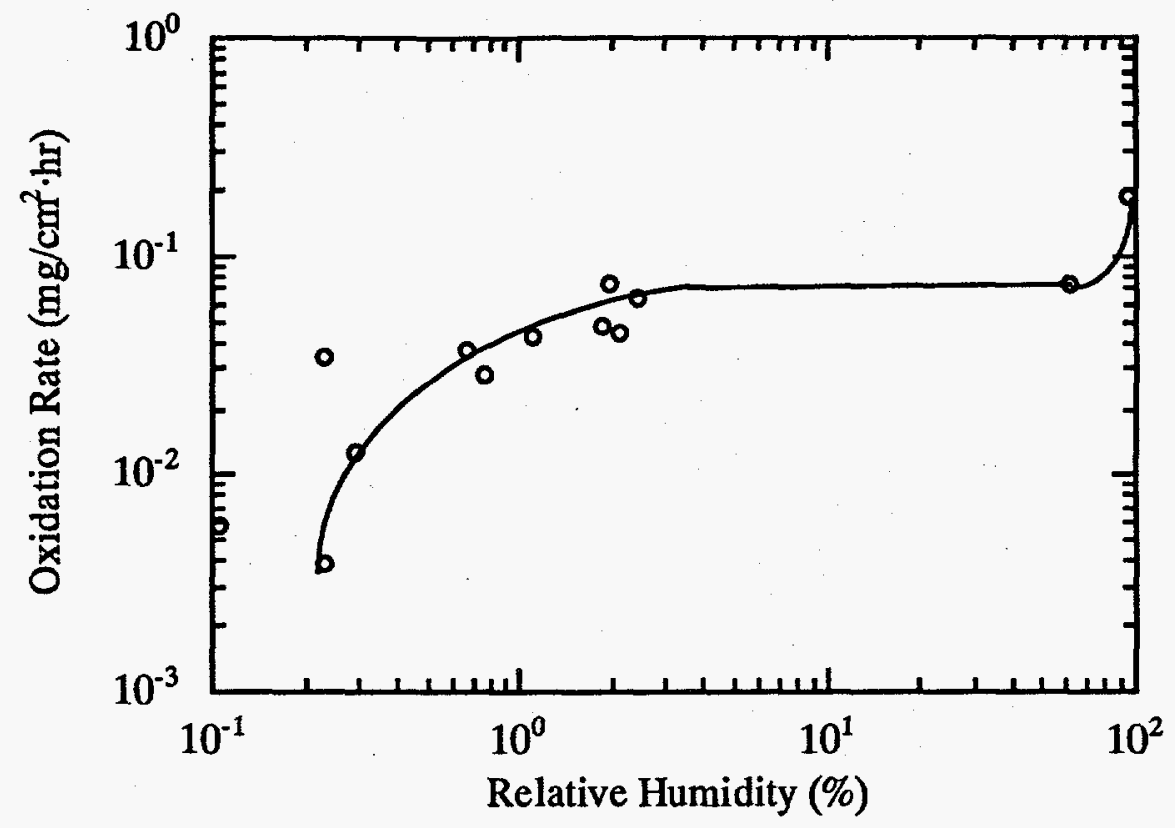

Fig. 8. Variation in plutonium oxidation rates with humidity (adapted from Raynor and Sackman, 1967). 


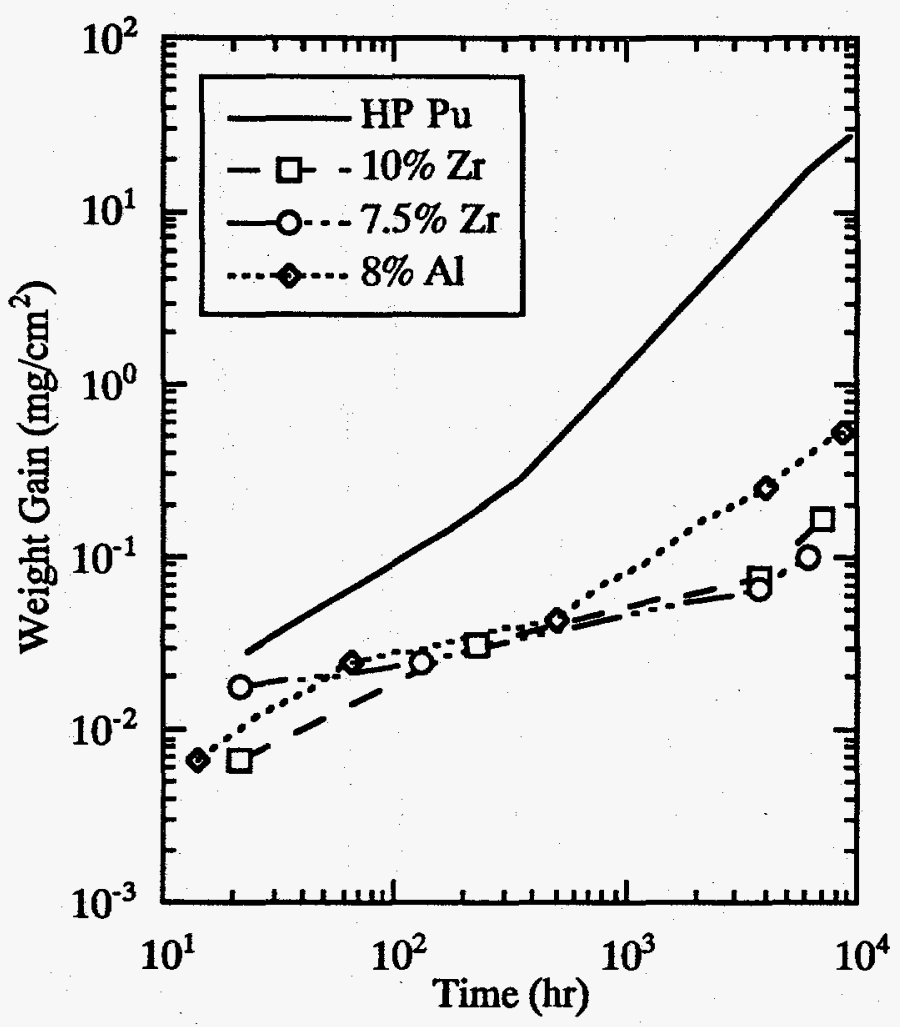

Fig. 9. The effect of several alloying additions on the oxidation rate of plutonium at $35^{\circ} \mathrm{C}$ in air containing $20 \%$ humidity (adapted from Waber, 1958). 


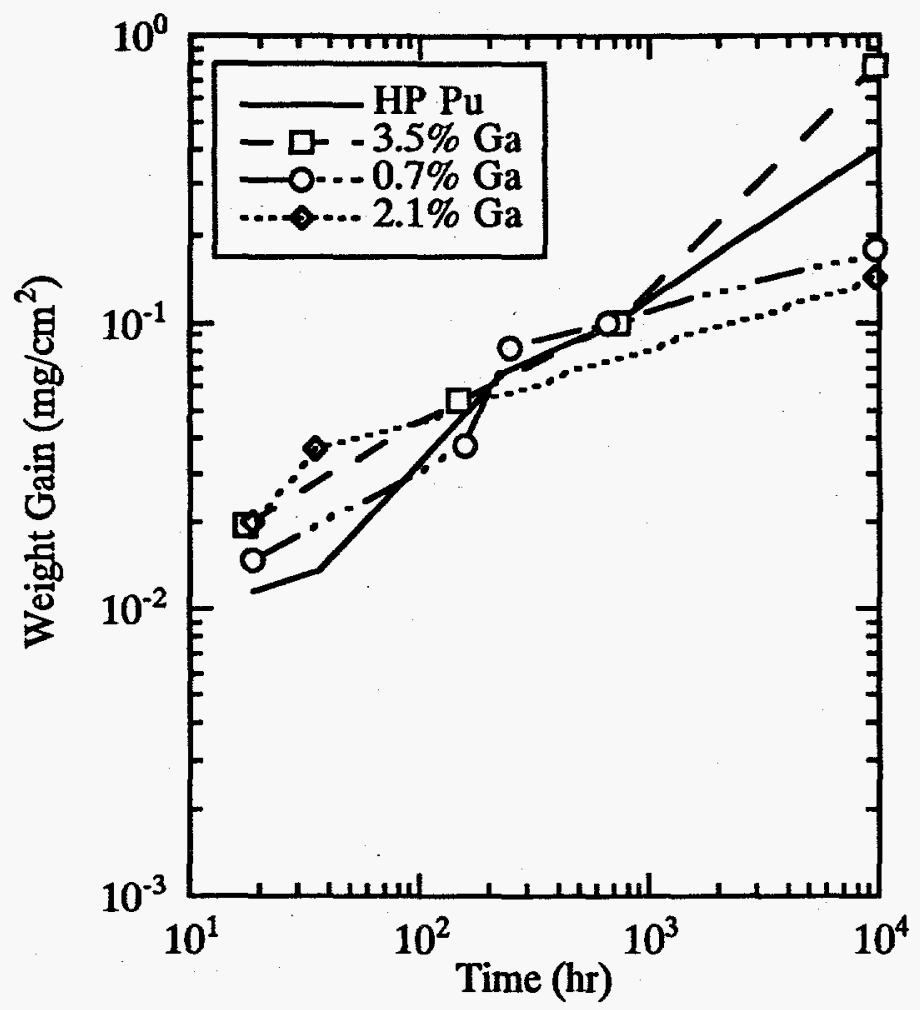

Fig. 10. The effect of $\mathrm{Ga}$ alloying additions on the oxidation rate of plutonium at $75^{\circ} \mathrm{C}$ in dry air (adapted from Waber, 1958). 


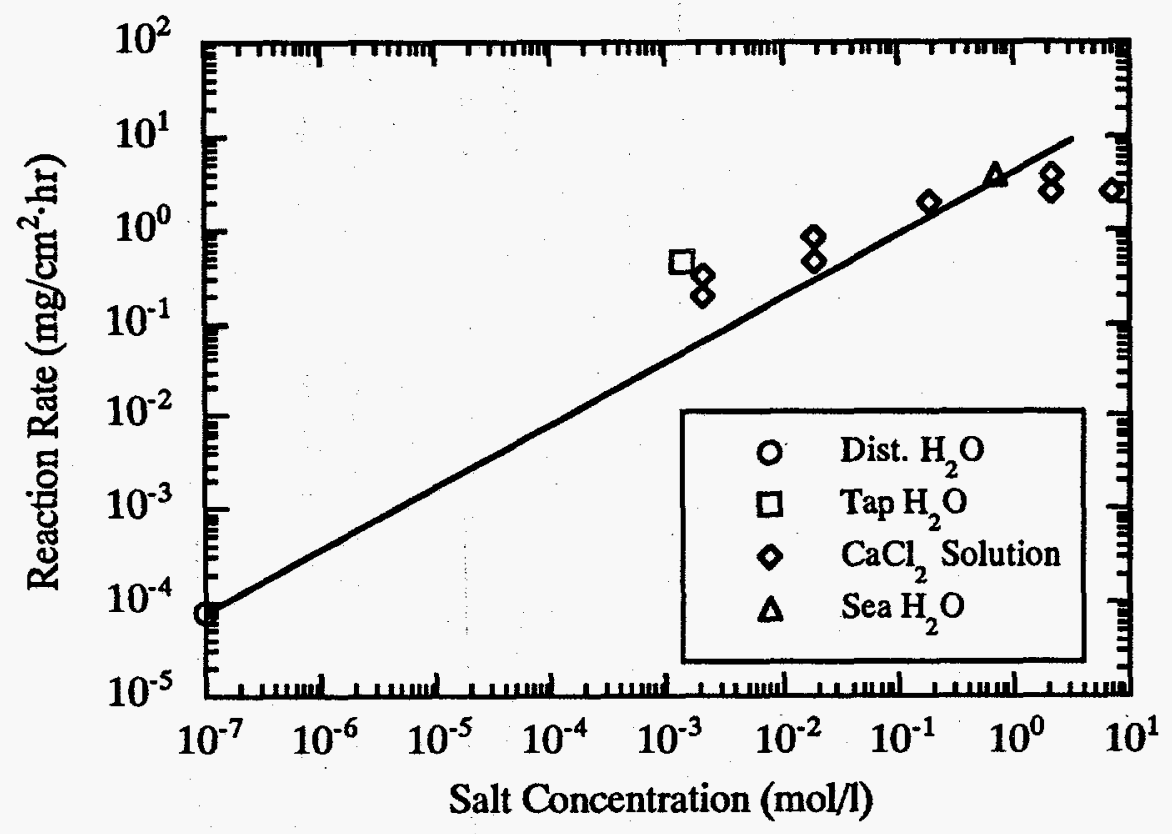

Fig. 11. The variation in plutonium corrosion rates in aqueous solutions at room temperature with anion concentraton (adapted from Hascke et al., 1983).

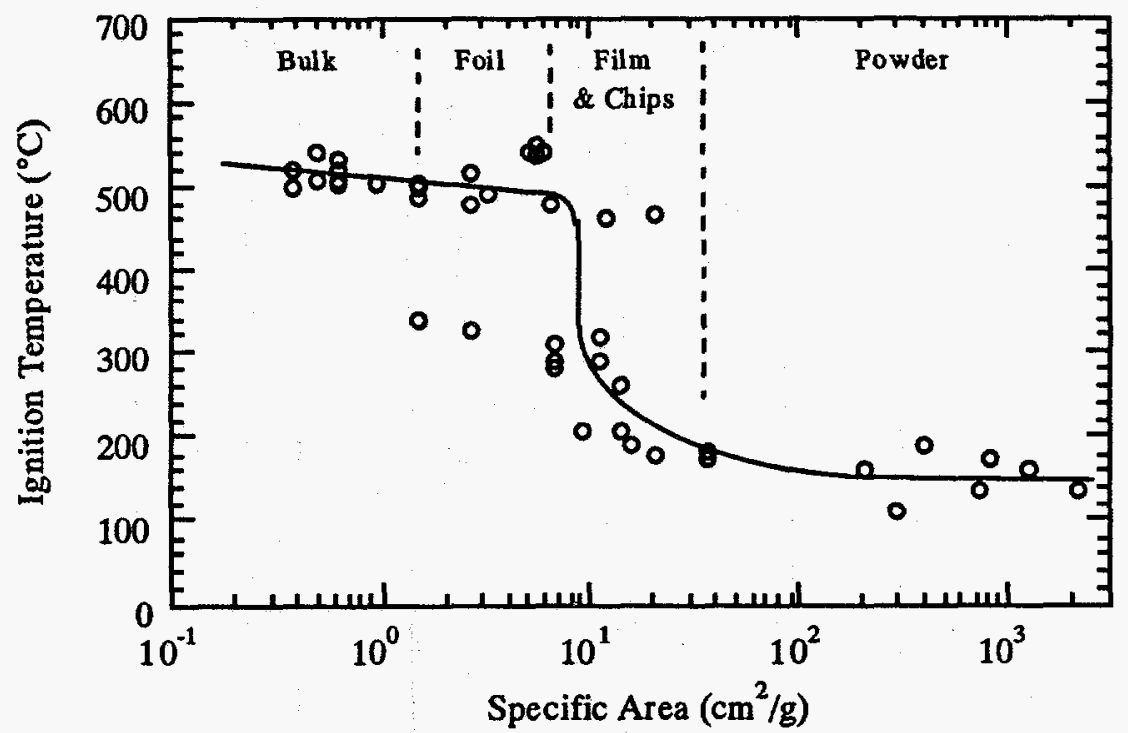

Fig. 12. Compilation of plutonium ignition temperatures in air and oxygen as a function of specific area (adapted from Stakebake, 1992a). 


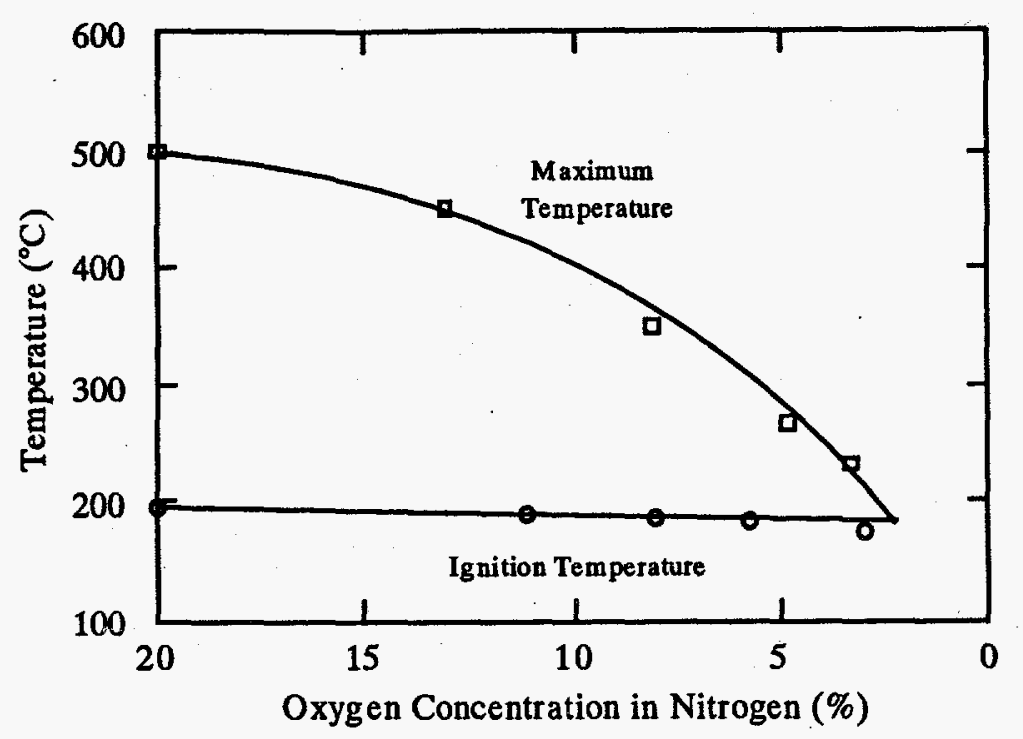

Fig. 13. Variation of plutonium ignition and burning temperatures with oxygen concentration in $\mathrm{N}_{2}-\mathrm{O}_{2}$ mixtures (adapted from Musgrave, 1971).

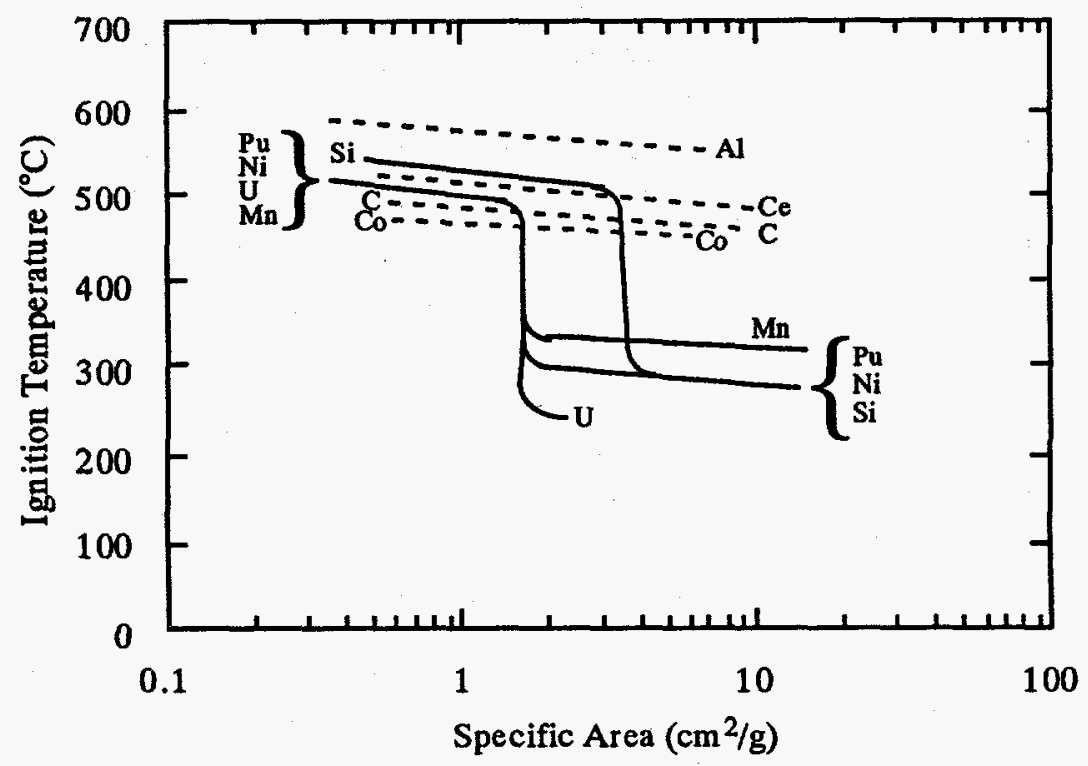

Fig. 14. Variation of ignition temperatures in air with specific area for $\mathrm{Pu}-2 \mathrm{a} / \mathrm{oX}$ alloy foils (adapted from Schnizlein and Fischer, 1964). 